\title{
Antlions (Neuroptera, Myrmeleontidae) along the North Caspian shore; distributional analysis and zoogeographical division of Caspian coast of Russia
}

\author{
VICTOR A. KRIVOKHATSKY ${ }^{1}$, ILHAMA G. KERIMOVA, ${ }^{2, \vartheta}$, VASILYI V. ANIKIN ${ }^{3}$, DMITRYI M. ASTAKHOV ${ }^{4, \dagger}$, \\ ANNA S. ASTAKHOVA ${ }^{5}$, ELENA V. ILYINA ${ }^{6}$, IGOR S. PLOTNIKOV ${ }^{1}$, JULIA V. SAMARTSEVA ${ }^{1}$ \\ ${ }^{1}$ Zoological Institute, Russian Academy of Sciences. Universitetskaya Emb., 1, St. Petersburg 199034, Russia \\ ${ }^{2}$ Institute of Zoology, National Academy of Sciences of Azerbaijan. A. Abbaszadeh str., 115, passage 1128, block 504, Baku Az1004, Azerbaijan. \\ Tel. +994-70-7119670, `email: ilkershah@mail.ru \\ ${ }^{3}$ Chernyshevskii Saratov State University. ul. AStrakhanskay 83, Saratov 410012, Russia \\ ${ }^{4}$ Volgograd State University. Universitetskiy pr., 100, Volgograd 400062, Russia \\ ${ }^{5}$ Volgograd Branch of the Russian Entomological Society, Lenin Avenue, 27, Volgograd 400066, Russia \\ ${ }^{6}$ Prikaspiyskiy Institute of Biological Resources, Daghestan Scientific Centre of the Russian Academy of Sciences. 45 M. Gadzhieva Str., Makhachkala \\ 367025, Russia
}

Manuscript received: 13 August 2019. Revision accepted: 26 December 2019.

\begin{abstract}
Krivokhatsky VA, Kerimova IG, Anikin VV, Astakhov DM, Astakhova AS, Ilyina EV, Plotnikov IS, Samartseva JV. 2020. Antlions (Neuroptera, Myrmeleontidae) along the North Caspian shore; distributional analysis and zoogeographical division of Caspian coast of Russia. Biodiversitas 21: 258-281. Zoogeographically regionalization of Northern Caspian territory, adjacent Eastern Caucasian and Volga-Ural regions were carried out by using the original cladistic program (CLA) based on faunistic investigations of Neuroptera, Myrmeleontidae. A total of 47 of elementary districts of physical geography or geobotanical mapping and 41 species of antlions were used for analyses in the Matrix. 46 elementary faunas were combined in the region into seven concrete faunas. The ConCaspian and Volga-Ural antlion faunas were mixed. Aspoeckiana uralensis Hölzel, 1969 was considered as superspecies with a complex of five subspecies with overlapping areas of distribution, associated in its origin with the spread of Northern antelopes (Saiga tatarica (Linnaeus, 1766), Gazella subgutturosa Guldenstaedt, 1780, Procapra gutturosa Pallas, 1777). At the North Caspian Shore Aspoeckiana uralensis uralensis Hölzel, 1969, and Aspoeckiana uralensis jakushenkoi Zakharenko, 1983, cohabited with the saiga antelope, using their paths for larval colonies. The dynamics of Macronemurus bilineatus Brauer, 1868 area over the past 100 years was described in detail. For some paleoenvironmental conditions of their origin and colonization of the Caspian region are reconstructed. The leading role of Turan in the formation of the fauna of the antlions is determined.
\end{abstract}

Keywords: Antlions, clasterisation, Northern Caspian region, systematics, zoogeography

\section{INTRODUCTION}

The territory of the Lower Volga region was previously considered as a zoogeographical transition zone between Europe and Asia base on the data of 16 species antlions distribution (Krivokhatsky Anikin 1996). According to the checklist of antlions ? from the European part of the former USSR byKrivokhatsky (1993), there was no zoogeographical regionalization of the region in detail. Principal boundaries of particular zoogeography outlined in the Volga-Ural region and Northern Caspian territory only in total Palaearctic schemes of diversity centers and elementary faunas of antlions (Krivokhatsky 1998; Krivokhatsky Emeljanov 2000). Preliminary study of antlions distribution in the Lower and Middle Volga was published in the Russian language by Krivokhatsky et al. (2016). In the present study, the primary fences recalculated and new coastal areas were added.

The faunas of the Caspian region and the interfluve of the Volga and the Ural rivers are mixed with each other. Myrmecaelurus trigrammus (Pallas, 1771) described from Samara-Yrgiz county and known recently as Ancient-
Mediterranean plain is widespread species. Two subspecies, Neuroleon nemausiensis piryulini Krivokhatsky, 2011 and Mesonemurus guentheri olgae Krivokhatsky, 2011 were described from Volga-Akhtuba plain, but distributed widely than Low Volga Region. There are no endemic speciesof Myrmeleontidae in VolgaUral and ConCaspian territory. Only specific sets of taxa with a ratio of their abundance in concrete faunas turned out to be unique for this region.

Geographic distribution of twenty species and species groups is described in detail in the annotated checklist. The rank of Creoleon remanei Hölzel, 1972 is lowed to subspecies of Creoleon plumbeus (Olivier, 1811). As a result, three subspecies are recognized within $C$. plumbeus: C. plumbeus plumbeus, C. p. tabidus (Eversmann, 1841) and C. p. remanei Hölzel 1972. The fauna of the Caspian region and the interfluve of the Volga and the Ural rivers is considered to be mostly Turanian in origin.

The distribution data of antlions among administrative regions of the former USSR were compiled by Krivokhatsky (1993) based on the published papers, starting from Hagen (1858), Ulianin (1869), and Yakowleff 
(1869). Some of sample collection localities were pointed in the species distribution maps in the publications (Aspöck et al. 1980; Krivokhatsky et al. 1996; Anikin 1996; Piryulin 1997; Krivokhatsky 2011). Collection materials examined listed in last revision of Russian Myrmeleontidae (Krivokhatsky 2011) and subsequent publications listed in the present paper.

\section{MATERIALS AND METHODS}

Old and recent collections of adult and larval stages of Myrmeleontidae from Volga-Ural plain, Lower Volga, Northern Caspian, and Eastern Caucasian territories have been collected, studied, and listed in special publications, mostly with participation of authors (Krivokhatsky 1993, 2000, 2012; Krivokhatsky and Anikin 1996; Krivokhatsky and Zakharenko 1996; Krivokhatsky and Rokhletzova 2004; Rokhletzova and Krivokhatsky 2006; Rokhletzova 2000; Krivokhatsky et al. 2003, 2016; Ilyina and Krivokhatsky 2012; Ilyina et al. 2014; Khabiev and Krivokhatsky 2014; Makarkin and Ruchin 2014). Previously published records based on doubtful identifications are listed and discussed (Krivokhatsky 2011).. New and interesting records are included in the annotated checklist.

The occurrence status of the taxa (species, subspecies) in the primary fence werw estimated by point scale: 0 . absent; 1 . recently singular, or all records came before 1980 only; 2. usual representatives in old collections and at the present time; 3. common taxa in appropriate season.

Primary fence was made up based on randomized plot from physiographic, land system and geobotanical mapping of East European Plain in ranks of county or elementary district (Gvozdetsky 1968; Fedina 1973; Isachenko 1985). As a cartographic basis for the application of primary elementary fences, we used a geographical map of the $70 \mathrm{~s}$ of the twentieth century, the original map for zoogeographical regionalization of Emeljanov (1974) in configuration of later publication (Emeljanov 2000). The final combined clusters of concrete faunas already displayed on a fragment of the map of the Western Palaearctic with the modern configuration of the rivers and banks of the new Aral and the Caspian. Because of the relative rarity of antlions in entomological collections, we combined primary fences, bringing them closer to localities with documented fixed localities. As example, many 'empty' or 'incomplete' natural areas had to join in a few primary areas in coastal Dagestan.

Primary Matrix includes distributional data on 41 species and subspecies of antlions along 63 (46 finally) primary fences of the North Caspian and Volga-Ural territories. The Matrix was completed in the original computer program by Plotnikov (Plotnikov et al. 2013), CLA, prepared, especially for biogeographical needs. Some of the distributional lines after completion remained empty. Due to the parametric variation of program, the empty lines were escaped and were not shown in the preliminary dendrograms. Empty fences at the map gradually were included into appropriate counties. After analyzing of first produced preliminary dendrograms of each cluster, every crosscut branch was verified. The contradictory areas were combined up again, the fences were remixed.

Photographs of antlions in nature were made by $D$. Astakhov (D.A.), E. Ilyina (E.I.), V.Krivokhatsky (V.K.) and kindly provided us by colleagues P. Gorbunov (P.G.), A. Kurochkin (A.K.) and the late D. Piryulin (D.P.). Photographs of collecting specimens prepared by V. Krivokhatsky and J. Samartseva.

\section{RESULTS AND DISCUSSION}

\section{Clasterisation}

The map with the approved primary elements used to build the latest versions of the dendrogram is shown in Figure 1. The program transformed the primary matrix (Figure 2) according to the specified parameters into a matrix of similarity coefficients (Figure 3). Based on that matrix, the program CLA built a dendrogram (Figure 4). Among the proposed program coefficients and methods of calculation, the most suitable parameters were SörensenChekanovsky coefficient (quantitative), calculated by the nearest neighbor (Figures 5-6).As example, Northern ConCaspian and ConCaspian Terrace County were gathered into one cluster, and Sarpin county was added to the Ergenin county. When using the SörensenChekanovsky index, the program does not compare the faunal lists, but the role of the species in ecosystems, that is, their numerical abundance in ecosystems. The studied fauna were divided into three compact clusters within which it is possible to isolate and describe a number of concrete fauna of antlions.

The main block of ConCaspian fauna $(C C)$ is divided into Western Turano-Anatolian (TA) and NorthTuranian (NT) ones. The first compact cluster, from left to right, unites the fauna of the three primary fences of TransCaucasia, partly of the North Caucasus (TalyshLenkoran, Kura-Aras and Low-Samur-Absheron counties). Within the ConCaspian fauna, it is designated as TransCaucasian (TC) concrete fauna. Caucasian-Anatolian subendemics (Nohoveus armenicus (Krivokhatsky 1993).

Cueta anomala (Navas 1915), Palpares libelluloides (Linnaeus, 1764) and Myrmecaelurus trigrammus (Pallas, 1771) are dominated (2-3); the most diversity of the genus Neuroleon Navas, 1909 (four taxa) is obvious in that fauna.

The associated cluster represents the fauna of Central Dagestan $(C D)$, which spread in the Sergokalin and Buinakskyi counties. It is closed by present $P$. libelluloides, but dominants and subdominants here are disagreeing: $M$. trigrammus, Creoleon plumbeus (Ol.).

Caucasian cluster includes Kukurtbash-Eldamskyi and Tersko-Andyiskyi counties. It belongs to the Foothill Dagestan $(F D)$ concrete fauna, which very poor in the number of species (four species only), but $P$. libelluloides and $M$. trigrammus have high abundance-2-3. This cluster occupies the smallest territory on the coast. 


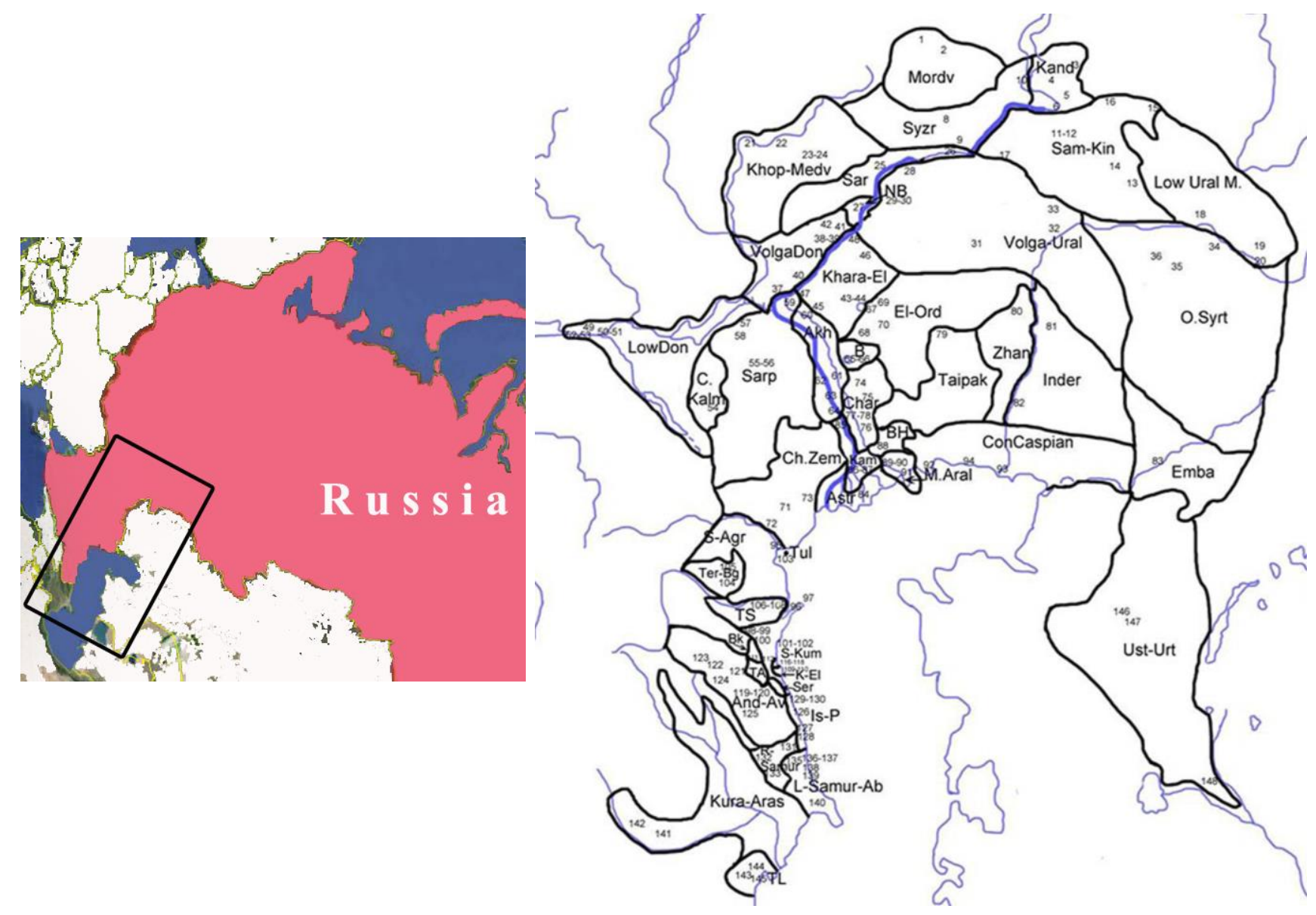

Figure 1. The location of the primary fences and main localities of antlions in the Northern ConCaspian, Volga region and Volga-Ural interfluves. Subscriptions: Mordvinian county (Mordv): 1. Temnikov, 2. Ruzaevka; Kandabulak-Sok county (Kand); 3 . Elkhovka; 4. Kurumoch; 5. Kandabulak; 6. Zhiguliovskyi Nat. Res. The location of the primary divisions and main localities in the Northern Caspian, Volga and Volga-Ural interfluve.Syzran-Khvalyn county (Syzr): 7. Pavlovka; 8. Staraia Kulatka; 9. Khvalynsk; 10. Shikovka; SamaraKinel county (Sam-Kin): 11. Gostevka; 12. Borskoie; 13. Tozkoie; 14. Buzuluk; Low Ural Mountain county (LowUral M.): 18. Orenburg, 19. Kuvandyk 20. Podgornoie; Khopior-Medveditza county (Khop-Medv): 21. Almazovskyi Nat. Res., 22. Balashov, 23. Ataevka, 24. Medveditza river; Saratov county (Sar): 25. Saratov 26. Volsk; Nizhniaia Bannovka county (NB): 27. Nizhniaia. Bannovka distr; Volga-Ural county (Volga-Ural): 28. Engels, 29. Krasnyi Kut 30. Diakovka 31. Alexandrov Gai, 32. Uralsk, 33. Vostochnyi; ConUral county (ConUral): 34. Sol'-Ilietzk; Obschyi Syrt county (O. Syrt): 35. Korsak-Bas Mnt. 36. Troizk Volga_Don county (Volga Don): 37. Volgograd, Sarepta, 38. Antipovka, 39. Chukhonostavka, 40. Dubovka, 41. Kamyshin, 42. Elanskaia; Khara-Elton counti (Khara-El): 43. Elton lake, 44. Khara river, 45. Kap-Jar proving ground, Jitkur, 46. Pallasovka, 47. Peschanka, 48. Rovnoie; Low Don county (Low Don): 49. Rostov 50. Novocherkassk, 51. Aksai, 52. Taganrog Salsk, 53. Azov, (Manych); Central Kalmykya county (C.Kalm): 54. Elista; Sarpin county (Sarp.): 55. Plodovitoie, 55. Godzhur, 56. Komsomolskyi, 57. Yashkul, 58. Privolnyi; VolgaAkhtuba county (Vol-Akh): 59. Volshskyi, 60. Kapustin Jar vill., 61. Akhtubinsk, 62. Nikolskoie, 63. Zagan-Aman, 64. Enotaevka; Baskunchak county $(B)$ : 65. Big Boghdo Mnt., 66. Baskunchak lake Elton-Ordin counti (El-Or): 67. Elton vil., 68 . Urda vil., 69. Dzhanybek, 70. г. Ulagan mt. env. Elton vil.; Chernyye Zemli county (Ch.Z): 71. Chernyye Zemli, 72. Andrayinskyi, 73. Barkhannyi; Charabaly county (Char): 74. Mikhailovka, 75. Charabaly, 76. Dosang, 77. Selitrennoe, 78. Vol'noie; Taipak county (Taipak): 79. Kalmikovo; ( Taipak) Zhanakazan county (Zhan): 80. Janakazan or Zhanakazan (Novayia Kazanka); Inder counti (Inder): 81. Inder lake. Inderborskyi, 82. Makhambet; Emba plain county (Emba): 83. Kul'sary; Astrakhan Island county (Astr): 84. Astrskhan Nat. Res.); Kamyziak county (Kam): 85. Zagan-Aman, 86. Astrskhan, 87. Kamyziak; Baer Hills county $(B H)$ : 88. Aksaraiskayia; Malyi Aral county (M.Aral): 89. Malyi Aral, 90. Baibek, 91. Ak-Kol; ConCaspian terrace county (ConCaspian): 92. Ganiushkino, 93. Atyrau, 94. Isatai; Sulak-Agrakhan county $(S-A g r)$ : 95. Biriuziak, 96. Agrakhan spit, 97. Chechen Island, 98. Shushanovka, 99. Nechaevka, 100. Almalo, 101. Sulak, 102. Krivaia balka Seal Island (Tul), 103. Seal Island ( Tulenyi); Tersko-Bazhigalian county (Ter-Bg): 104. Terekli-Mekteb, 105. Yuzhno-Sukhokumsk; Tersko-Sulakskyi county (TS): 106. Kizliar, 107. Terskaia, 108. Krainovka, 109. Makhachkala, 110. Karaman; Buinakskyi county $(B k)$ : 111. Buinaksk = Temir-Khan-Shura); Sarykum-Kumtorkalinskyi county $($ S-Kum): 112. Sarykum, Kumtorkala; Tersko-Andyiskyi county $(T A)$ : 113. Dylym, 114. Gertma, 115. Termenlik; Kukurtbash-Eldamskyi county $(K$-El): 116. Tarki-Tau Mnt, 117. Agach-aul, 118. Talghi; Sergokalin county (Ser): 119. Sergokala, 120. Kajakent; Andyisko-Avarian county (And$A v)$ : 121. Chirkata, 122. Agvali, 123. Gimry, 124. Kosob,125. Gunib, Keger; Isberbash-Papas county (Is-P): 126. Isberbash, 127. Papas, 128. Derbent, 129. Turali, 130. Manas; Rubas-Samurian county (R-Samur): 131. Shur-Dere, 132. Rutul, Kufa, 133. Akhty, Jaba; LowSamur-Absheron county (L-Samur-Ab): 135. Magaramkent, 136. The Mouth Of Samur, 137. Belidzhi, 138. Shabran, 139. Siazan, 140. Baku; Kura-Aras county (Kura-Aras): 141. Ordubad, 142. Nakhichivan; Talysh-Lenkoran county (TL): 143. Lerik, 144. Salian, 145. Lenkoran; Ust-Urt county (Ust-Urt): 146. Beineu, 147. Akjigit, 148. Nukus 


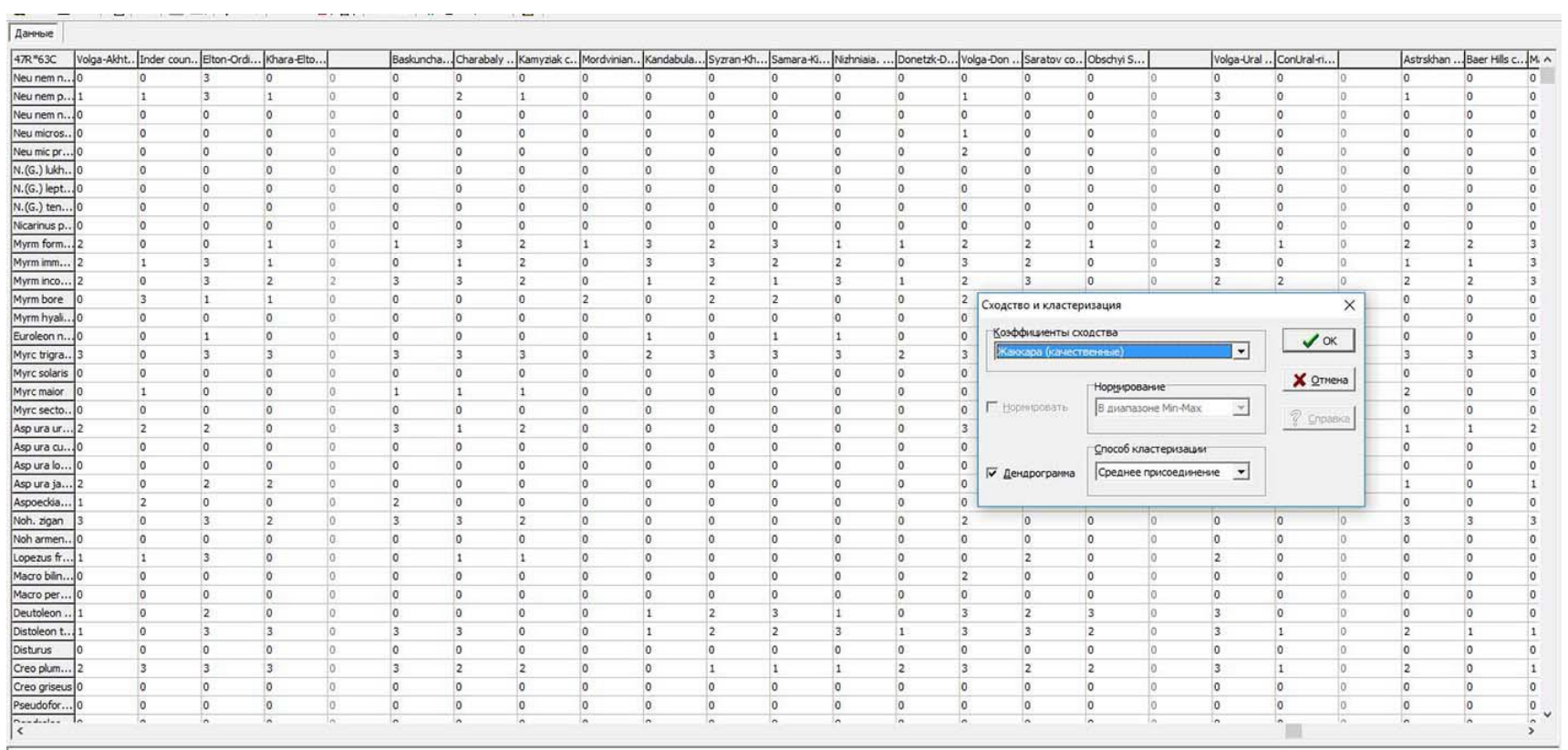

Figure 2. Fragment of Primary Matrix of the distribution of species of antlions by the primary territorial divisions (fences) in the CLA program with the window to choice parameters of cauterization

\begin{tabular}{|c|c|c|c|c|c|c|c|c|c|c|c|c|c|c|c|c|c|c|c|c|c|c|c|c|}
\hline \multirow{4}{*}{  } & \multicolumn{24}{|c|}{\begin{tabular}{l|l} 
Deraporparma & Kos
\end{tabular}} \\
\hline & Talysh_e & ratare & Low-Samur-t & Aandrisho-Av & Pubass: & & & 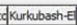 & 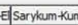 & intersto-Andy & Ey Tersho-Sulak & cotosth & disberbashf & Agrabl & d I Island - & - Low Don cou & | Sarpin count & nf Central Kalm/ & nf Chernyye Ze & Ahopior-Med & d zhanakazan | & Trapak coun & nt volga-Ak & at $\ln n$ \\
\hline & & 0,6250 & 0,2917 & 0,2000 & 0,2941 & 0,2667 & 0,3333 & 0,1818 & 0,3899 & 0,2143 & 0,3899 & 0,3529 & 0,2667 & 0,1875 & 0,1429 & 0,2241 & 0,2222 & 0,2222 & 0,2000 & 0,1111 & 0,2083 & 0,1176 & 0,1739 & 0 \\
\hline & 0,6250 & 1 & 0,4583 & 0,2222 & 0,3000 & 0,2778 & 0,4000 & 0,1333 & 0,3182 & 0,2353 & 0,3182 & 0,2857 & 0,2105 & 0,1500 & 0,1111 & 0,3000 & 0,1818 & 0,2381 & 0,1667 & 0,1429 & 0,2222 & 0,0952 & 0,1923 & - \\
\hline Low-Samur-t: & 0,22917 & 0,4583 & 1 & 0,2857 & 0,4991 & 0,3333 & 0,4348 & 0,1000 & 0,4167 & 0,1818 & 0,5455 & 0,3333 & 0,2174 & 0,2727 & 0,1364 & 0,3478 & 0,2917 & 0,2917 & 0,2222 & 0,1600 & 0,3571 & 0,2174 & 0,3333 & 0 \\
\hline Andrisko-Av & 0,2000 & 0,2222 & 0,2857 & 1 & 0,2857 & 0,2500 & 0,2500 & 0,1250 & 0,2353 & 0,0033 & 0,3125 & 0,1176 & 0,1538 & 0,1538 & 0,2000 & 0,2857 & 0,1250 & 0,1250 & 0,1111 & 0,2308 & 0,1905 & 0,0714 & 0,1500 & 0 \\
\hline Rubas:Samu & 0,2241 & 0,3000 & 0,4091 & 0,2257 & 1 & 0,1176 & 0,2000 & 0,0000 & 0,3158 & 0,0625 & 0,3389 & 0,2105 & 0,1176 & 0,1875 & 0,0667 & 0,2941 & 0,2222 & 0,2222 & 0,1429 & 0,1111 & 0,2609 & 0,0556 & 0,2273 & 0, \\
\hline Sergokala cc & 0,2667 & 0,2778 & 0,3333 & 0,2500 & 0,1176 & 1 & 0,5000 & 0,2500 & 0,4667 & 0,1667 & 0,4667 & 0,3333 & 0,3333 & 0,4545 & 0,3000 & 0,2667 & 0,3571 & 0,1875 & 0,2353 & 0,2143 & 0,3000 & 0,4545 & 0,2632 & 0, \\
\hline 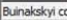 & 0,3333 & 0,4000 & 0,4348 & 0,2500 & 0,2000 & 0,5000 & 1 & 0,1538 & 0,5000 & 0,4615 & 0,5000 & 0,3889 & 0,3125 & 0,4000 & 0,2857 & 0,4118 & 0,2632 & 0,2000 & 0,1818 & 0,2222 & 0,4091 & 0,2353 & 0,3182 & 0, \\
\hline Kurkhosash Et &  & 0,1333 & 0,1000 & 0,1250 & 0,0000 & 0,2500 & 0,1538 & -1 & 0,1429 & $\begin{array}{l}0,3333 \\
\end{array}$ & 0,1429 & 0,0769 & 0,1111 & 0,2500 & 0,1667 & 0,0833 & 0,0833 & 0,0833 & 0,0714 & 0,1000 & 0,0526 & 0,1111 & 0,0558 & 0, \\
\hline arrkamktur & 0,3839 & 0,3182 & 0,4167 & 0,2353 & 0,3158 & 0,4667 & 0,5000 & 0,1429 & 1 & 0,1765 & 0,6471 & 0,5294 & 0,4667 & 0,5774 & 0,3571 & 0,3399 & 0,3889 & 0,2500 & 0,2273 & 0,2778 & 0,4545 & 0,2941 & 0,4286 & 0. \\
\hline ersko-Andy & 0,2143 & 0,2 & 0,1 & 0,0833 & 0,0 & 0,1 & 0,46 & 0,3 & 0,1 & me & 0,1765 & 0,2000 & 0,0769 & 0,2727 & 0,10 & 0,2 & 0,133 & 0,21 & 0,1 & 0,1538 & 0,2000 & 0,07 & 0,1579 & 0 \\
\hline Tersko-Sulat & 0,3899 & 0,3182 & 0,5455 & ,3125 & 0,3899 & 0,4667 & 0,5000 & 0,14 & 0,6471 & 0,17 & 等 & 0,5294 & 0,4667 & 0,5714 & 0,35 & 0,3899 & 0,3889 & 0,25 & 0,22 & 0,2778 & 0.4545 & 0,29 & 0.4286 & 0 \\
\hline Terskofosth & 0,3529 & 0,2857 & 0,3333 & 0,1176 & 0,2105 & 0,3333 & 0,3899 & 0,0769 & 0,5294 & 0,2000 & 0,5294 & 1 & 0,6667 & 0,5385 & 0,4167 & 0,4375 & 0,4375 & 0,3529 & 0,3899 & 0,4000 & 0,5000 & 0,3333 & 0,5556 & 0, \\
\hline isberbashp. & 0,2667 & 0,2105 & 0,2174 & 0,1538 & 0,1176 & 0,3333 & 0,3125 & 0,1111 & 0,4667 & 0,0769 & 0,4667 & 0,6667 & 1 & 0,4545 & 0,6250 & 0,3571 & 0,3571 & 0,1875 & 0,2353 & 0,4167 & 0,3684 & 0,3333 & 0,4118 & 0, \\
\hline Sulabk-Agalth & 0,1875 & 0,1500 & 0,2727 & 0,1538 & 0,1875 & 0,4545 & 0,4000 & 0,2500 & 0,5714 & 0,2727 & 0,5714 & 0,5385 & 0,4545 & 1 & 0,4444 & 0,2667 & 0,3571 & 0,1875 & 0,1667 & 0,3077 & 0,3684 & 0,3333 & 0,4118 & 0, \\
\hline Seal Island. & 0,1429 & 0,1111 & 0,1364 & 0,2000 & 0,0667 & 0,3000 & 0,2857 & 0,1667 & 0,3571 & 0,1000 & 0,3571 & 0,4167 & 0,6250 & 0,4444 & 1 & 0,2308 & 0,2308 & 0,1429 & 0,2000 & 0,2727 & 0,2778 & 0,3000 & 0,3125 & 0, \\
\hline Low Don cou & 0,2941 & 0,3000 & 0,3478 & 0,2857 & 0,2841 & 0,2667 & 0,4118 & 0,0833 & 0,3389 & 0,2143 & 0,3389 & 0,4375 & 0,3571 & 0,2667 & 0,2308 & & 0,5714 & 0,3750 & 0,3333 & 0,5385 & 0,4500 & 0,2667 & 0,5000 & 0, \\
\hline & 0,2222 & 0,1818 & 0,2917 & 0,1250 & 0,2222 & 0,3571 & 0,2632 & 0,0833 & 0,3889 & 0,1333 & 0,3889 & 0,4375 & & 0,35 & 0,23 & 0,5719 & 1 & 0,5 & 0,50 & 0,4286 & 0,5263 & 0,5933 & 0,6875 & 0 \\
\hline $\mathrm{akalm}$ & 0,2222 & 0,2381 & 0,291 & 0,12 & 0 & 0,1875 & 0,2000 & 0,0833 & 0,2500 & 0,2143 & 0,2500 & 0,3529 & & 0,1875 & 0,14 , & 0,3750 & 0,5 & & 0,71 & 0,2500 & 0,4500 & 0.46 & 0,6875 & 0, \\
\hline Chenvive ze & 00,2000 & 0,1667 & 0,2222 & 0,1111 & 0,1 & 0,2353 & 0,1818 & $0,0:$ & 0,2273 & 0,1 & 0,22 & 0,33 & 0,2353 & 0,1667 & 0,20 & 0,33 & 0,5000 & 0,71 & . & 0,22941 & 0,4091 & 0,50 & 0,6111 & 0, \\
\hline Khopior Med & 0,1111 & 0,1422 & 0,1600 & 2308 & 0,1111 & 0,2143 & 0,2222 & 0,1000 & 0,2778 & 0,1538 & 0,2778 & 0,4000 & 0,4167 & 0,3077 & 0,2727 & 0,5385 & 0,4286 & 0,2500 & 0,2941 & & 0,5000 & 0,2143 & 0,4706 & 0, \\
\hline Zhanalazana & 0,2083 & 0,2222 & 0,3571 & 0,1905 & 0,2609 & 0,3000 & 0,4091 & 0,0526 & 0,4545 & 0,2000 & 0,4545 & 0,5000 & 0,3684 & 0,3684 & 0,2778 & 0,4500 & 0,5263 & 0,4500 & 0,4091 & 0,5000 & . & 0,3684 & 0,7000 & 0, \\
\hline TTipk cou & 0,1176 & 0,0952 & 0,21 & 0,07 & 0,0556 & 0,4545 & 0,2353 & 0,11 & 0,2941 & 0,0769 & 0,2941 & 0,3333 & 0,3333 & 0,3333 & 0,3000 & 0,2667 & 0,5833 & 0,4615 & 0,5000 & 0,2143 & 0,3684 & & 0,5000 & 0 , \\
\hline Volga-Alth & 0,1739 & 0,192 & 0,33 & 0,15 & 0,2273 & 0,263 & $0,31$. & 0,05 & 0,4286 & 0,15 & 0,42 & 0,555 & 0,4118 & 0,41 & 0,31 & 0,50 & 0,6875 & & 0,6111 & 0,4706 & 0,7000 & 0,5000 & & 0 , \\
\hline Inder count & 0,15 & 0,1250 & 0,1 & 0,0000 & 0,0952 & 0,1111 & 0,2500 & 0,0000 & 0,1818 & 0,1250 & 0,1818 & 0,3333 & 0,1765 & 0,1765 & 0,2143 & 0,2105 & 0,2105 & 0,3529 & 0,4706 & 0,1667 & 0,3043 & 0,2500 & 0,4000 & 1 \\
\hline Etton-Ordin & 0,2174 & 0,2308 & 0,3214 & 0,0909 & 0,2174 & 0,3158 & 0,4286 & 0,0556 & 0,4091 & 0,2105 & 0,3478 & 0,4500 & 0,3158 & 0,3158 & 0,2222 & 0,4000 & 0,5556 & 0,4737 & 0,4236 & 0,3684 & 0,7500 & 0,4706 & 0,6500 & 0 \\
\hline Whara fition & 0,1500 & 0,1739 & 0,2800 & 0,1875 & 0,1500 & 0,3333 & 0,2500 & 0,0769 & 0,3684 & 0,1250 & 0,3684 & 0,5000 & 0,4286 & 0,3333 & 0,30 & 0,4375 & 0,64429 & 0,5333 & 0,5625 & 0,6154 & 0,5799 & 0,5385 & 0,6471 & 0, \\
\hline Baschunchak & 0,27 & 0,1739 & 0,18 & 0,11 & & 0,2500 & 0,19 & & & & - & & 0,3333 & 0,323 & 0,2 & 0,27 & - & 0,53 & & & 0,3636 & 0,4 & $x^{2}$ &  \\
\hline Charabalyc ce & 0,2632 & 0,2 & 0,26 & & 0,2 & 0,3 & 0,36 & & 0,5 & 0,1 & & $0, \pi$ & 0,50 & 0,5 & 0,38 & 0,4 & 0,50 & 0,50 & $0,52$. & 0,37 & 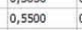 & 0,55000 & 0,7059 & 0, \\
\hline Kanyzak co & 0,15 & 0,13 & 0,2 & & 0,16 & & 0,3 & 0,0 & 0,33 & 0,1 & 0,3 & 0,6429 & 0,4615 & 0,4615 & 0,45 & 0,2941 & 0,3750 & 0,37 & 0,5000 & 0,3333 & 0,4500 & 0,5833 & 0,5882 & 0, \\
\hline Mordvinianc & 0,00 & 0,0000 & 0,0000 & 0,12 & 0,0000 & 0,0000 & 0,00 & 0,000 & 0,066 & 0,00 & 0,06 & 0,0769 & 0,1111 & 0,1111 & 0,1667 & 0,0000 & 0,0000 & 0,0000 & 0,0000 & 0,22222 & 0,1111 & 0,0000 & 0,0588 & 0 , \\
\hline Kandabciab-; & 0,2000 & 0,1579 & 0,1250 & 0,2727 & 0,1250 & 0,3636 & 0,2500 & 0,1250 & 0,4000 & 0,0833 & 0,3125 & 0,3571 & 0,5000 & 0,3636 & 0,3333 & 0,3846 & 0,3846 & 0,1250 & 0,1765 & 0,6000 & 0,3889 & 0,2500 & 0,3529 & 0 \\
\hline Syzran Khvav & 0,1875 & 0,1500 & 0,1200 & 0,1538 & 0,0556 & 0,3333 & 0,2353 & 0,1111 & 0,3750 & 0,0769 & 0,2941 & 0,4286 & 0,6000 & 0,3333 & 0,4444 & 0,4615 & 0,4615 & 0,1875 & 0,2353 & 0,7000 & 0,4444 & 0,3333 & 0,4118 & 0 \\
\hline & 0,2500 & 0,2000 & 0,1600 & $m$ & $x_{1}$ & 0,4167 & 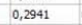 & 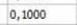 & 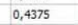 & 0,0714 & & 0.00 & 0.545 & rat &  & & 4296 & 0.76 & דברכי & 364 & 5000 & 0,3077 & 3899 & 0, \\
\hline & al 0 & 0,2 & 0,250 & & 0,2 & & $0,3 !$ & & & & & & & & & & & & & & & & & \\
\hline & & & & & & & & & & & & & & & & & & 040 &, 2500 & 545 & . & 2500 & 75 & \\
\hline
\end{tabular}

Figure 3. Fragment of Matrix with similarity coefficients, generated in program CLA

The first cluster of large NT block is North Dagestanian concrete fauna $(N D)$, which distributed among TerskoSulakskyi, Sulak-Agrakhan, and Seal Island fences. It was characterized by pit-builder antlions, connected with small cattle grazing.

Next three seaside counties (Tersko-Bazhigalian, Isberbash-Papas, Sarykum-Kumtorkalinskyi) of coastal Sandy Dagestan fauna $(S D)$ were characterized by high level of diversity (15 mostly uncommon species). The northern boundary of $P$. libelluloides comes through
Sarykum-Kumtorkalinskyi county (2). The full set of species of the genus Myrmeleon Linnaeus, 1767 is characteristics for the whole concrete fauna.

The Sandy Dagestanian cluster turned out to be similar to the neighboring association of Volga-Ural (VU) fauna (Samara-Kinel, Low Ural Mountain, Syzran-Khvalyn, Kandabulak-Sok counties), which is inhabited by almost all representatives of Myrmeleon except southern Myrmeleon hyalinus Olivier, 1811 replacing it the northern Myrmeleon formicarius Linnaeus, 1767 increases its number to index 3. 




Figure 4. The dendrogram, generated in program CLA, with Jakkard coefficient, average connection

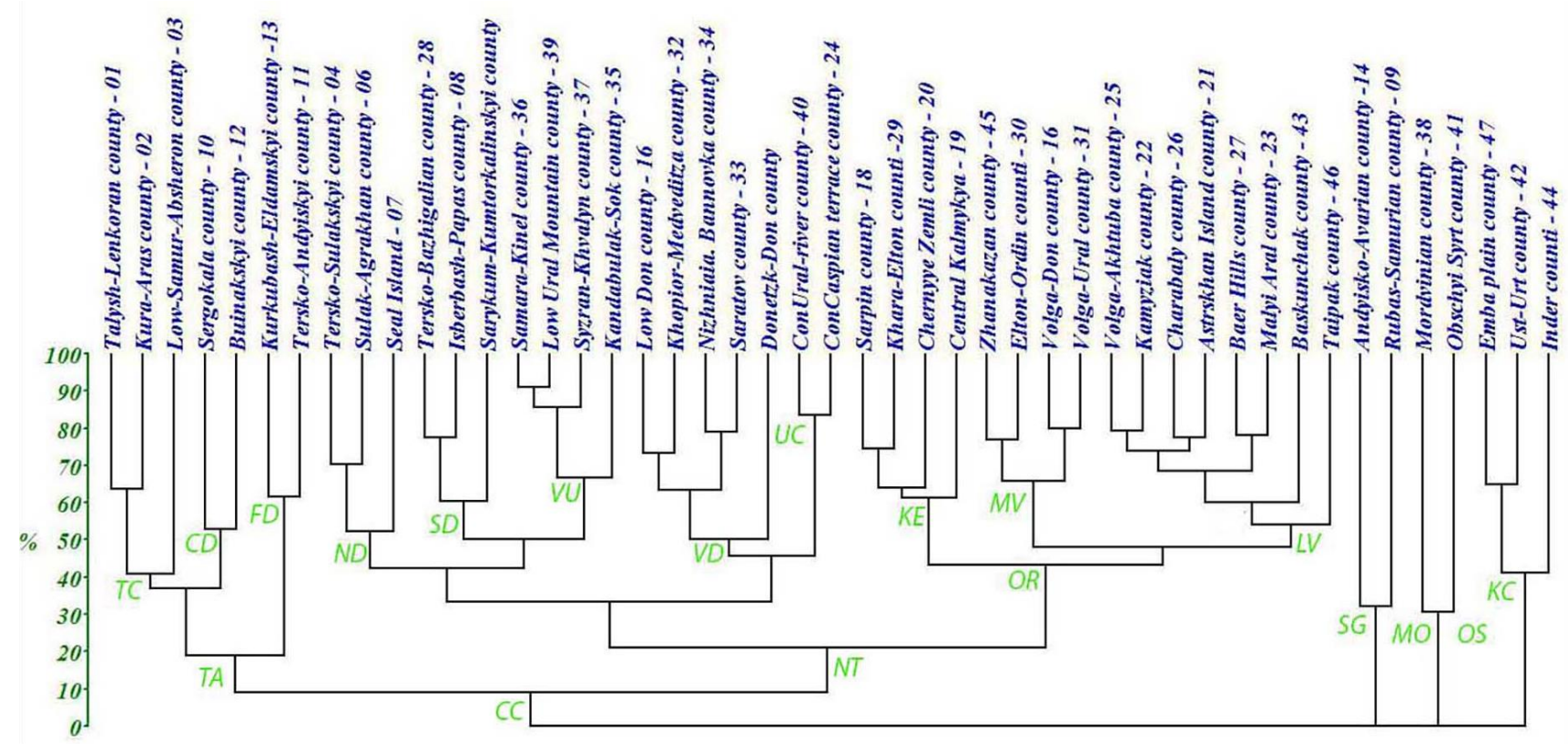

Figure 5. The dendrogram, generated in program CLA, with Sörensen-Chekanovsky coefficient, calculated by the nearest neighbor. Subscriptions: Concrete faunas: CC: ConCaspian; CD: Central Dagestan; FD: Foothill Dagestan; KE: Kalmyk-Elton; KC: KaszakhCaspian; ND: North Dagestanian; NT: NorthTuranian; LV: Lower-Volga; MO: Mordvinian county; MV: Middle-Volga; OR: Ordyn; OS: Obschyi Syrt county; SD: Sandy Dagestan; SG: Samur-Gunib concrete fauna; TA: Turano-Anatolian; TC: TransCaucasian; UC: Uralo-Caspian; VD: Volga-Don; VU: Volga-Ural.

Next cluster, five fences, combined antlion faunas of Middle Volga and River Don interfluve (Volga-Don fauna: VD). The most species rich among them are Nizhniaia Bannovka and Saratov counties (10 species each) followed by Khopior-Medveditza county ( 9 species). The highest abundance species (3) in those locations is Myrmeleon inconspicuous Rambur, 1842; subdominates (2) are M.trigrammus and Distoleon tetragrammicus (Fabricius,
1798). The species of thickets, like Distoleon tetragrammicus and Megistopus flavicornis (Rossi, 1790), are characteristic for most of the counties.

This cluster contrasted to divided association of coastal Uralo-Caspian (UC) concrete fauna (ConUral-river and ConCaspian terrace counties). In total, there are 10 species, 8 of them are common. Each of them has a minimum abundance-1-2. 




Figure 6. The distribution map of faunas in the Caspian region and the Volga-Ural interfluve corresponding to the Dendrogram. Designations as in Figure 5

The larger cluster, Ordyn $(O R)$, consists of KalmykElton $(K E)$ cluster, Middle-Volga $(M V)$, and Lower-Volga $(L V)$. The Western Kalmyk-Elton cluster brings together four primary fences on both banks of the Volga. This concrete fauna unites remote local faunas, similar to the presence of not common species (1-2), Mesonemurus guentheri olgae Krivokhatsky, 2011, Neuroleon nemausiensis pyriulini Krivokhatsky, 2011, Aspoeckiana uralensis Hölzel, 1969, Nohoveus zigan (Aspöck, Aspöck et Hölzel 1980).

The Middle-Volga territory (Zhanakazan, Volga-Don, Elton-Ordin, and Volga-Ural counties) wide expanded around Middle Volga Plane, formally from Don to Ural Rivers. Here each fence resides on 3-4 representative of the tribe Myrmeleontini, whose larvae are obligated to build a funnel in the sand. The fauna is characterized by large abundance (2-3) of Aspoeckiana uralensis uralensis, Hölzel, 1969, which is cohabited with the saiga antelope, using its paths for larval colonies.

Lower-Volga fauna part expanded onto the southern part of the Volga-Ural interfluve (Volga-Akhtuba, Kamyziak, Charabaly, Astrskhan Island, Baer Hills, Malyi Aral, Baskunchak and Taipak counties). It's characterized by the joint dwelling of species of thickets (D.tetragrammicus) and open spaces (Deutoleon lineatus (Fabricius, 1798), N. nemausiensis pyriulini, Creoleon plumbeus (Olivier, 1811), A.uralensis, Lopezus fedtschenkoi (McLachlan, 1875), M.inconspicuus, Myrmeleon bore (Tjeder 1941). The antlion Myrmeleon immanis Walker, 1853 only is numerous species (2-3) in all
8 primary fences. A.uralensis also dominates in any counties.

Three right clusters are completely separated from the common bush of Volga-Caspian fauna of antlions and inexplicably dissimilar among themselves.

First one separate cluster of 2 branches (AndyiskoAvarian and Rubas-Samurian counties) corresponds to Samur-Gunib concrete fauna $(S G)$. It differs from other Dagestanian ones by presence of Megistopus flavicornis (Rossi, 1790), Neuroleon microstenus propinquus (Navás 1911.) and by the absence of high abundance of other species.

Next duplex one also consists of branches, belonged to different concrete faunas, ( $M O$-Mordvinian fauna) and (OS-Obschyi Syrt fauna). Mordvinian fauna is a northern element of boreal influence and includes only two not common $(1,2)$ species, Myrmeleon formicarius and $M$. bore.

Fauna of Obschyi Syrt county is separated due to dominant Deutoleon lineatus (3), subdominant Distoleon tetragrammicus (2), in poor (5 species) faunal structure.

Last cluster combines Kaszakstanian Concaspian fences (Emba plain, Ust-Urt, Inder counties), characteristic for separate Kaszakh-Caspian concrete fauna $(K C)$. White spot between these three areas do absolutely unstudied for the fauna of antlions. The Kaszakstanian Concaspian fauna is unique among others by presence of turano-gobian Acanthaclisis pallida McL.

In order to understand the faunistic composition of each of the described clusters, it is necessary to present a generalizing faunistic list of the entire region.

\section{Annotated check list of main species of interest}

A list of the integrated fauna of North Caspian and Volga-Ural Plains consist of 20 species and species group taxa of antlions (Myrmeleontidae), most of which have quite homogeneous populations within Russian Plain. Only a few species are heterogeneous in that part of the distribution area. Subspecific and infrasubspecific structure of those species (Creoleon plumbeus (O1.), Aspoeckiana uralensis Hz., Lopezus fedtschenkoi (McL.), Acanthaclisis occitanica (Vill.)) were discussed in species essays, but it is not used in cladistic comparison of local faunas.

Valid status of names and the order of their listing are pattern after the catalogue "Antlions (Neuroptera: Myrmeleontidae) of Russia" (Krivokhatsky 2011). We present annotated check list of 20 species below:

\section{Palpares libelluloides (Linnaeus, 1764)}

Materials. About 100 specimens are from Russian Dagestan and other Southern ConCaspian territories. The last collecting data was published in the revision of the species group (Krivokhatsky et al. 2017).

Distribution. Western Palearctic is striking with its bright species having a wide Mediterranean distribution area (South Europe, Caucasus, Turkey, and the Middle East of Iran). The distribution areasof this species reachs Caspian Sea Shore close to Large Caucasus Range. Due to the penetration of subtropical conditions from Transcaucasia, in Terek-Sundzhin elementary district the 
northern boundary of distribution of $P$. libelluloides was formed.

The adult stage of Palpares libeluloides spreads beyond the bounds of true subtropical landscapes and occupies biotopes suitable for the development of larvae in an adjacent zone. Thereby the permanent populations of adventive Mediterranean $P$. libelluloides (Figure 7) at the branches of Sarukum Dune and on the Agrakhan Split have been occurring. In the Transcaucasian part of the ConCaspian shore, two closely related species of the genus, Palpares libelluloides and P. turcicus Koçak, 1976 (Figure 8) inhabit neighboring biotopes, sometimes in the same landscape fences (Krivokhatsky et al. 2017; Kerimova Krivokhatsky 2018).

Megistopus flavicornis (Rossi, 1790)

Materials. More than 100 specimens are from Middle and Low Volga Regions and Caucasus.

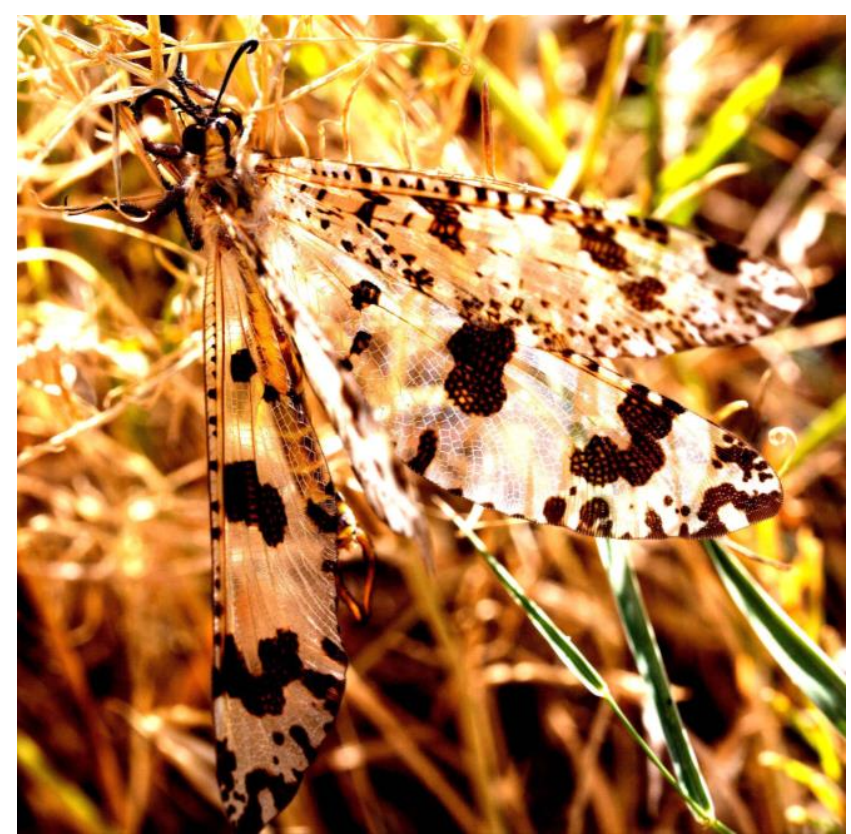

Figure 7. Palpares libelluloides, male, Shabran, Azerbaijan, Photograph I.K.

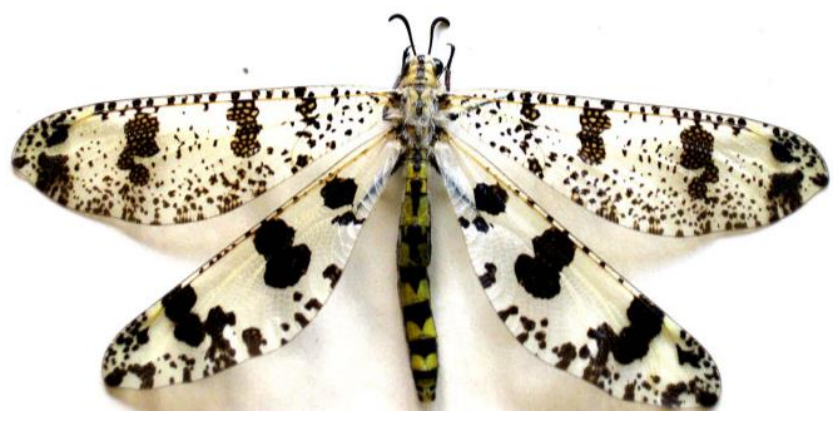

Figure 8. Palpares turcicus, female, Ordubad, Azerbaijan, Photograph I.K.
Distribution. Central and Southern Europe (from Portugal to Poland, Romania, Bulgaria, Moldavia and Ukraine, European part of Russia), Turkey, Caucasus, Turkmenistan, Iran. The species is European nemoral originated, Ancient-Mediterranean in distribution, which associated in the examined area to the timberland and brakes. To the East of Volga River was a not registered, but skirts the Caspian from the south. Everywhere and permanently its populations are very scanty: in each collection from each locality there are usually not more than three specimens. At the same time, it is too hard to find imago in nature: adult has mimetism like spider web in the wings (Figure 9); it is easier to catch them at night in the light (Figure 10).

Deutoleon lineatus (Fabricius, 1798)

Materials. About 30 specimens from Middle Volga, Volga-Ural Regions and North Caucasus.



Figure 9. Megistopus flavicornis: Antipovka, Photograph V.K

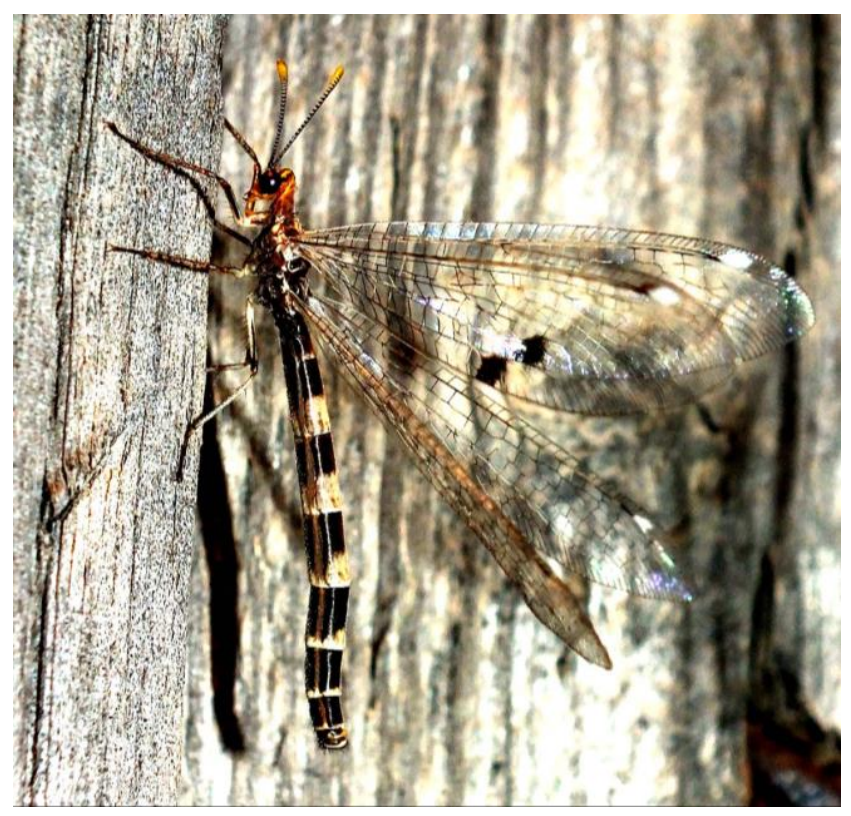

Figure 10. Megistopus flavicornis: Volgograd, Photograph D.A. 


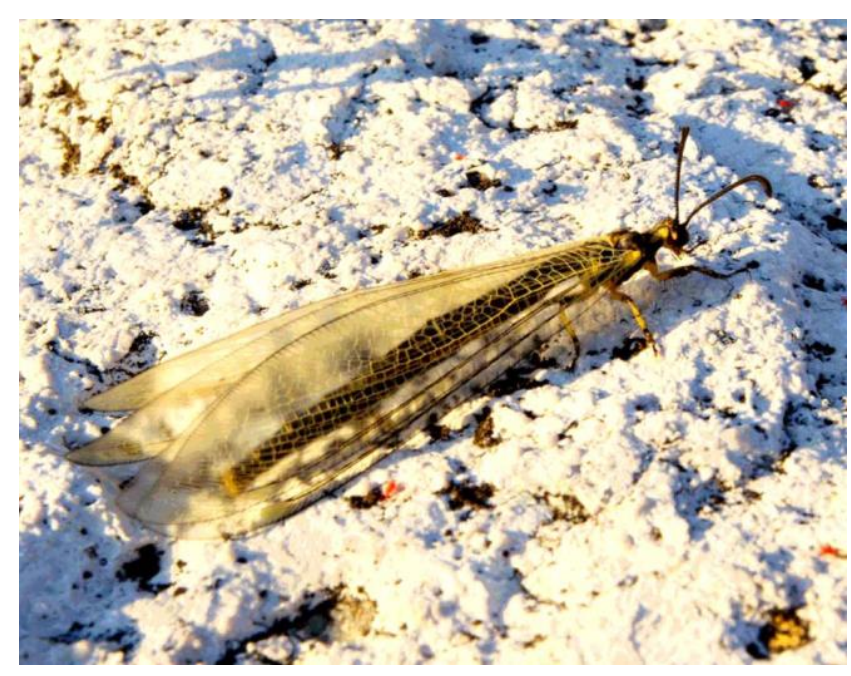

Figure 11. Deutoleon lineatus lineatus, male, Kandabulak, Photograph A.K.

Orenburg Prov., $1 \mathrm{~m}, 12 \mathrm{~km} \mathrm{~W}$ of Novotroitsk, Guberlya River valley, $51^{\circ} 15^{\prime}$ N, $58^{\circ} 07^{\prime}$ E, 5.07.2018, P. Gorbunov.

Distribution. Scythian steppe Euro-Siberian species that is known from Western Europe to Mongolia and China. At the researched territory the $D$. $l$. lineatus (Fabricius, 1798) is occurred only. The name of other subspecies D. l. turanicus Navás, 1927 should not be conducted with biogeografical or historical Turan on the Caspian Sea Shore; that taxa was described by L. Navás from the small village the Turan close to Kyakhta (Troitskosavsk, Buryatia) at the boundary with Mongolia.

At the Russian Plane, the populations of the single unmixed subspecies D. l. lineatus mostly occupied hillocky steppe landscapes and connected ravine-gully net of Volga and Ural Basins with a continuous range of distribution in Foothills of South Ural Range. The Eastern PannonianDnestrovian nucleus of range connected with SouthUralian and later with Kazakhian nuclei by force of anthropogenous steppe passes into agro landscapes.

Ant lion individuals hiding in grass and disturbed during collecting, fly very slowly and become easily visible. For this reason, $D$. lineatus is the most frequently registered species among the protected species included in the Red List of Samara Region of Russia (Sharonova, Kurochkin, 2015). Due to ease of detection of the slowly flying individuals, they give an impression of the species being common. However, after the few flying antlions have been collected, there are no additional individuals. That is a common tragedy for conspicuous and spectacular insects of our fauna. D. lineatus is unpretentious as an object at rest (Figure 11), butit attracts attention when flying.

In our judgment in Central Palearctic, D. lineatus indicates geographic province Obschiy-syirt, which contain Obschiy Syirt plateau, CisUralian plateau and BugulminBelebei upland in steepe zone of Russian plain. Extrapolated to the species area entirely, we can confidently conduct this Scythian species to the syirt-knoll form of steppe relief. Among the observed faunas, this species has been determined as specific for Lower-Volga and Obschyi Syrt concrete faunas. However, neither Southern nor Western boundaries of $D$. lineatus coincide with the boundaries of clusters distinguished, in spite of the fact that the species does not reach the Caspian seashore and transects the Volga to the West at the Saratov area only. Together with second subspecies, D. lineatus indicates European-Altai elementary antlion fauna in Palearctic (Krivokhatsky Emeljanov 2000).

\section{Distoleon tetragrammicus (Fabricius, 1798)}

Materials. About 200 specimens from Middle Volga, Volga-Ural Regions and Caucasian countries. Orenburg Prov., $1 \mathrm{~m}, 5 \mathrm{f}, 12 \mathrm{~km} \mathrm{~W}$ of Novotroitsk, Guberlya River valley, 51 ${ }^{\circ} 15^{\prime} \mathrm{N}, 58^{\circ} 07^{\prime}$ E, 5.07.2018, P. Gorbunov, Saratov reg., 2 f, $5 \mathrm{~km} \mathrm{~W}$ of Khvalynsk, Khrenov, $52^{\circ} 29^{\prime}$ $\mathrm{N}, 48^{\circ} 03^{\prime} \mathrm{E}, \mathrm{h}=302 \mathrm{~m}, 4-14.07 .2016$, V. Anikin; Volgograd reg., 1 f, Babaev vill., Don river, 49o11' N, 44o01'E, 7.07.2016, D. Astakhov; Dagestan. 1f, Turali, 12.06.2007, E. Ilyina; 2 f, Makhachkala, 18, 20.07.2008, E. Ilyina; 2 m, Makhachkala, 18.09.2008, E. Ilyina.

Distribution. Six specimens were collected recently in Orenburg Prov. (Guberlya River valley), that is the NorthEastern known locality of species. Widespread EuropeanMediterranean species anciently known from Southern Russia, for instance, was described from Sarepta (at present was included into Volgograd) under the name Myrmeleon flavomaculatus Eversmann, 1841 (Figure 12) and from Geok-Tapa in Azerbaijan under the name Formicaleo mesmini Navás, 1921 (Figure 13). Latterly the species is quite common in many districts of Low and Middle Volga, Volga-Ural and North Caucasian Regions. In any localities of Stavropol and Krasnodar Regions it could be absolutely dominant.

Adults of D. tetragrammicus are lodged inside leafage of single trees or under forest canopy in tree-plantings (Figure 14). The method of population accounting and catching is simple; if one of collectors shakes branches and others catch frightened antlions (Krivokhatsky et al. 2003).

Neuroleon nemausiensis (Borkhausen, 1791) 2011 .

Syn. Neuroleon nemausiensis piryulini Krivokhatsky,

Materials. More than 100 specimens, including type series and adjacent specimens from Middle-Volga, VolgaUral Regions, Northern Caucasus and Con-Aral Area. Orenburg reg. 1 f, Akoba vill., Akbulak env., 2930.06.2013, A. Shapovalov; Kazakhstan. $35 \mathrm{~m}$ and f, Aktobe Reg., Aiyrkyzyl Sands, Irgyz River Valley, $48^{\circ} 35^{\prime} \mathrm{N}, 60^{\circ} 60^{\prime} \mathrm{E}, 6.07 .2018$, A. Ivanov.

Distribution. Euxinio-Turanian subspecies is easy to distinguish from other two outside Western and Eastern spread subspecies. Rare in ConCaspian territory, $N$. nemausiensis piryulini relatively regularly occurs at the certain places on the sands of Volga-Ural interfluve and Northern-Eastern Caucasus (Figure 15). Last large collection (35 specimens) cames from the upper reaches of the river Emba Aiyrkyzyl Sands, Irgyz River Valley, 48³5' N, 6060' E (Aktobe Reg., Kazakhstan), 6.07.2018 from A. Ivanov. That locality is extremely eastern from the known range. 


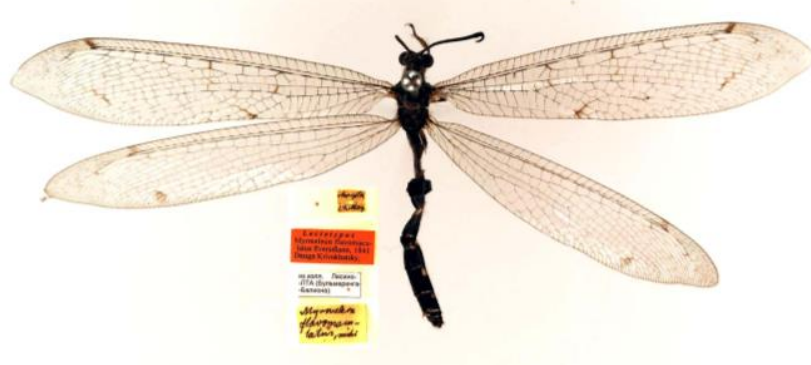

Figure 12. Myrmeleon flavomaculatus Eversmann, 1841, paralectotype, female, Sarepta

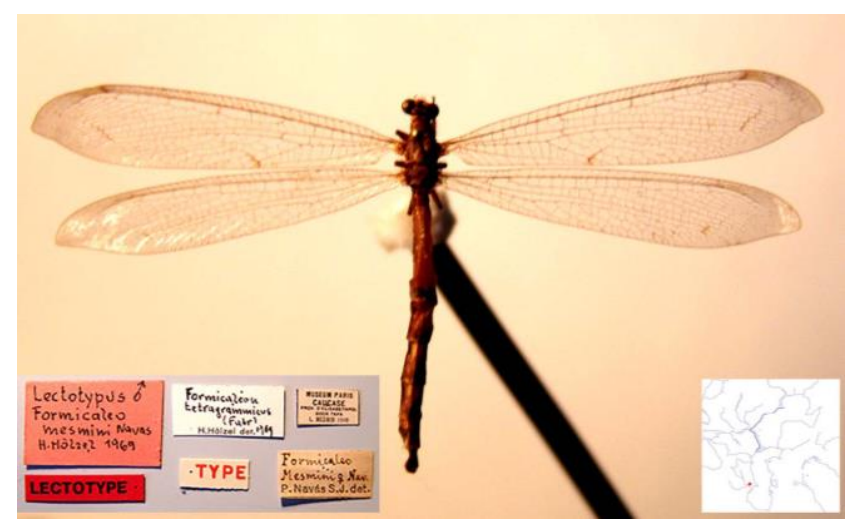

Figure 13. Formicaleo mesmini Navás, 1921, lectotype female, Geok-Tapa

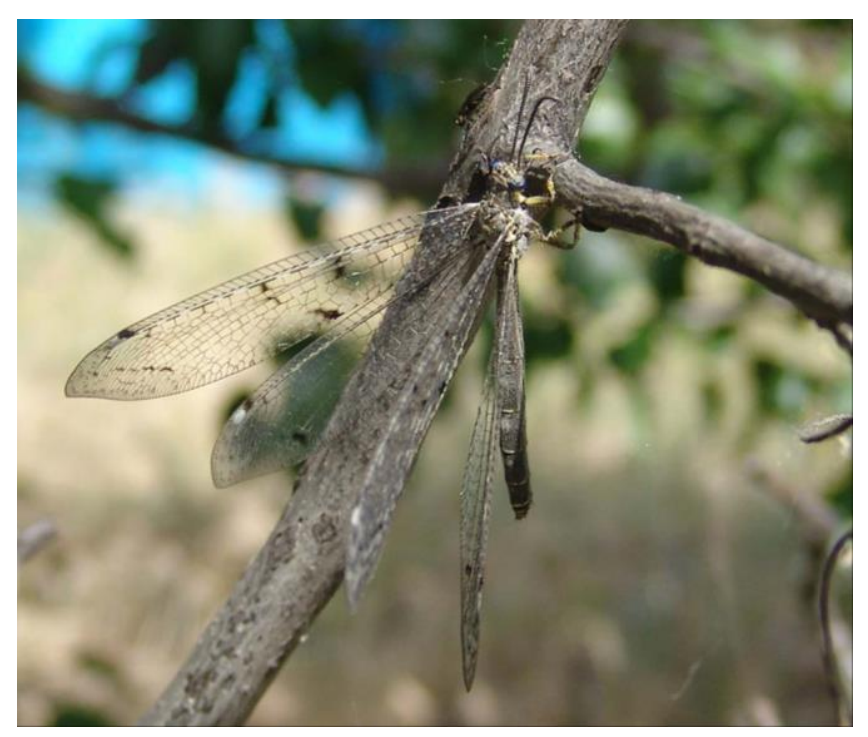

Figure 14. Distoleon tetragrammicus, Nizhniaia. Bannovka, Photograph VK

Neuroleon microstenus (McLachlan, 1898)

Syn. N. microstenus microstenus (McLachlan, 1898), N. microstenus propinquus (Navás, 1911)



Figure 15. Neuroleon nemausiensis piryulini Kriv., holotype, Urda



Figure 16. Neuroleon microstenus propinquus. female, lectotype, Crimea

Materials. Fourty specimens from Caucasus, VolgaDon interfluve, and North Caspian region. Armenia. $1 \mathrm{~m}$, Erevan env., zoo, ay light, 1.09.1955, A. Avetjan; $1 \mathrm{~m}$, Erevan env., zoo, ay light, 19.09.1959, S. Vardikan; $1 \mathrm{f}$, Erevan env., 13.10.1959, S. Vardikan; $1 \mathrm{~m}, 1 \mathrm{f}$, Megry, 611.08, 15-16.09.1977, Lisezkyi, № Zakharenko 5402, 5420; 1f, Megry, 24.08.1977, Lisezkyi, № Zakharenko 5374, 'Distoleon kabulensis Hz., Zakharenko det.'; 2 m, Aigedzor, 8.09.1977, Lisezkyi, № Zakharenko 5441, 5442; Nakhichevan. 1f, Buzgov vil., 7.09.1977, Lisetskyi, № Zakharenko 5345.

Distribution. This species is widespread EastMediterranean species. In Russia, two easy distinguished subspecies presented: larger one the N. m. microstenus, looks like the type described from Algeria, known from the mountains in Dagestan, but in Rostov, Krasnodar and Volgograd regions there is smaller one with contrast pictures on wings the N.propinquus Navás, 1911a, described from Crimea (Figure 16,17) (Krivokhatsky 2011). Precisely that subspecies, which occurs in any localities in the Volga-Don interfluve is included in our sphere of interests. 




Figure 17. Neuroleon microstenus propinquus. male, Volgograd, Photograph D.A.

\section{Neuroleon lukhtanovi Krivokhatsky, 1996}

Materials. About 40 specimens from Chirkata and Sarykum in Dagestan. Species so local and sporadic, that there are no new data on collection in Dagestan since last report (Krivokhatsky et al. 2016).

Distribution. The species belongs to the subgenus Neuroleon (Ganussa) with Afro-Gobian type of distribution area. Its far detached fragments of areal are spread in thoroughly torrid deserts of Irano-Turan, and local populations till now are known from Uzbekistan, Turkmenistan (Krivokhatsky 1996), Iran (Mirmoayedi et al. 1998), Dagestan, Kazakstan, Kirghizstan, (Khabiev Krivokhatsky 2014) and Georgia (Dobosz et al. 2017). Two populations of $N$. lukhtanovi, in sandy dunes of Sarykum and in the sands of submontane trough Chirkata proposed to include to the Red Data Books of Russia and the Dagestan Republic (Ilyina et al. 2016). Possible ways of penetration of these populations, known as Dagestanian refugium in Quaternary have been proposed. The intrusion could be connected with terrestrial Caucasus-Kopetdag bridge in Miocene or with Turanian biota expansion round the Caspian Sea up to Sarukum during Pra-Amudarja deflation in Pliocene (Figure 18-19).

\section{Macronemurus bilineatus Brauer, 1868}

Materials. About 50 old and fresh collecting samples from South Russia and Ukraine.

Distribution. Nemorum-steppe, Middle-EuropeanEuxinian-Con-Black-sean: Greece, Albania, Chernogoria, Slovenia, Romania, Hungary, Bulgaria, Romania, Turkey, Armenia, Azerbaijan, Ukraine; in Russia, known from the European steppe only (Krivokhatsky 2011).

The collecting dates onto the south of later USSR ventured draw attention to the abrupt of species reduction at the beginning of XX century. That reduction has been estimated as omnipresent, but does not affected on the local populations. After the collection of the period "Raised virgin soil", preserved in ZIN collection (region of the Don Cossacks, 1924, for instance), there were no new indications from these places.

Few populations from foothills of Crimea and Caucasus have been alive after collectivization and soviet break fresh ground. From these regions only old collections (19401960) have been preserved. Thereupon, after 1990, quite safe populations were registered by us in Ukraine, where at the end of 20th century M. bilineatus was associated with naturally protected Stipa steppe on the solid rocks ("Stone Graves", "Proval'e", "Kazantip", "Karadag"). Thus, M. bilineatus could be characterized as species, which reduces own area and abundance on the North Caucasus and onto Rostov Region under the anthropogenous impact of plowing up of virgin lands. That factor has over populations from awkward lands-microrefugia on the slopes and in the unused drafts.



Figure 18. Neuroleon lukhtanovi, female from Dagestan

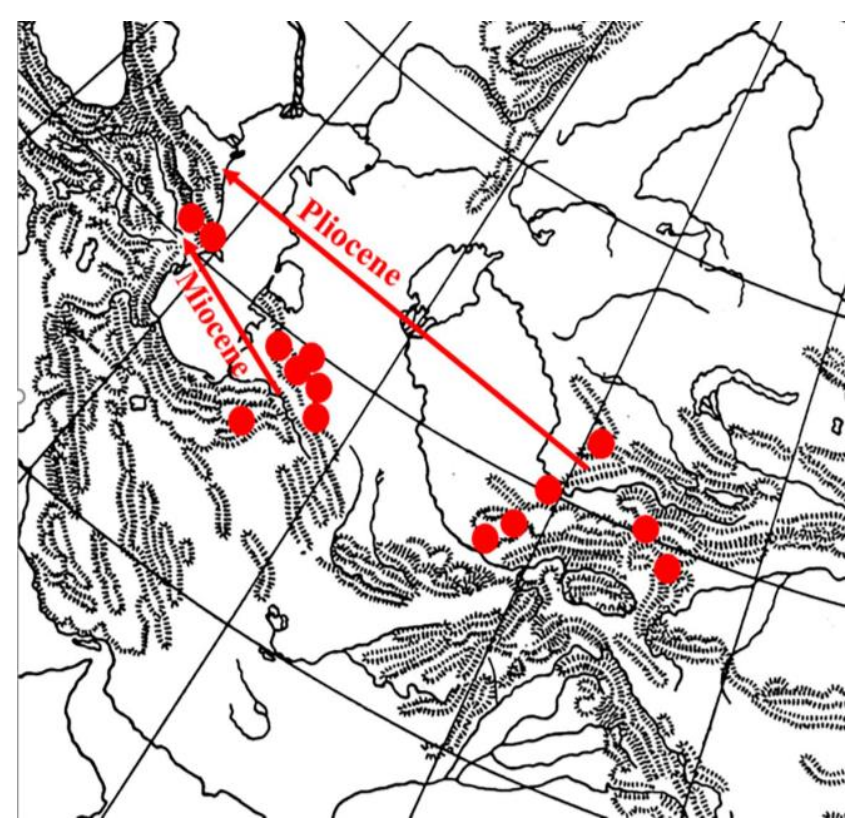

Figure 19. Map with recent localities and possible ways of invansion of Neuroleon lukhtanovi from Middle Asia to Northen Caucasus. 


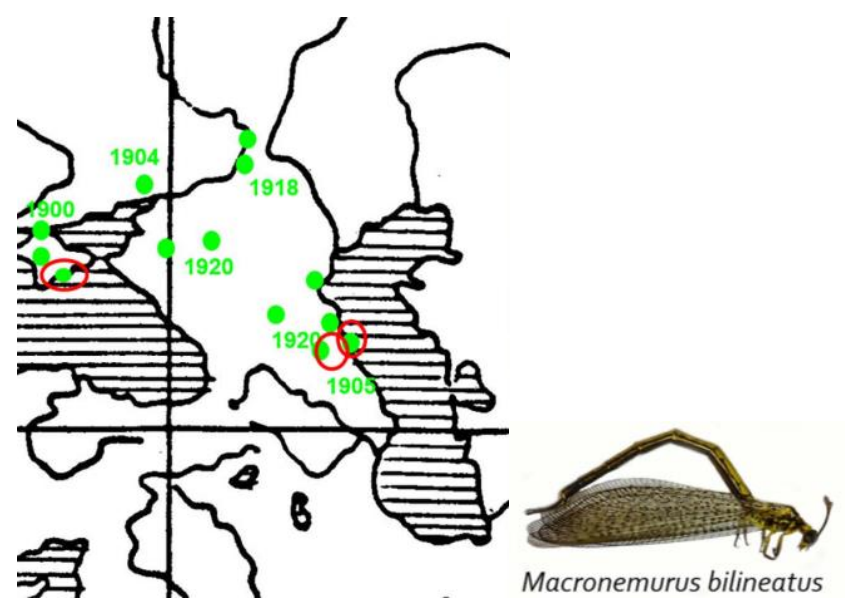

Figure 20. Macronemurus bilineatus at the beginning of 20th century. Red circles-sub mountain refuges in the period of depression

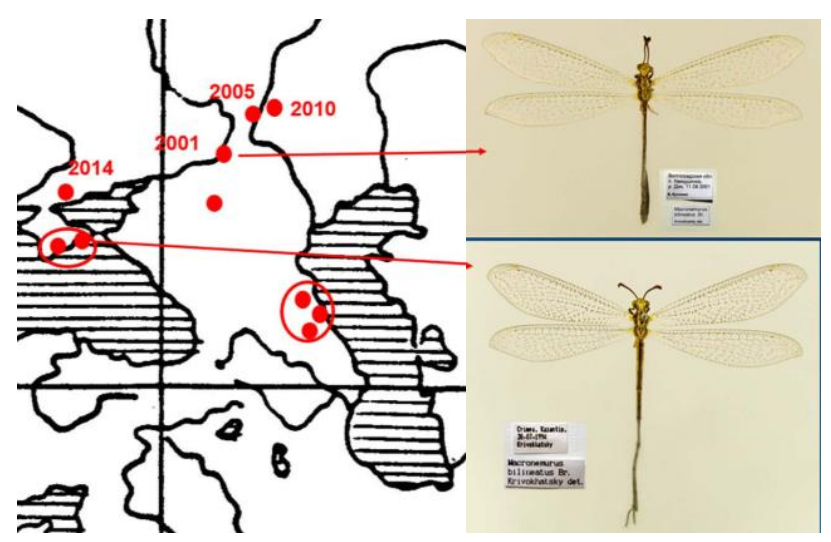

Figure 21. Macronemurus bilineatus at the beginning of $21 \mathrm{st}$ century. Red circles-submountain refuges in the period of depression.

Agriculture disorganization and overgrowing of agricultural lands at the end of XX century conduced to recultivation of natural ecosystems. Up to now the abundance of $M$. bilineatus approached to renewal in the middle of the former area of distribution, and the east boundary became to go to the Volga River, judging by our last records (Figure 20-21).

Extant focuses of the $M$. bilineatus after the forties, the Sarykum and Karadagh populations, at present implement a donor function in a restoration of the Dnepro-Don and the Volga-Don parts of species areas, which were eliminated in Soviet period by the development of virgin lands.

\section{Mesonemurus guentheri Hölzel, 1970}

Syn. Mesonemurus guentheri olgae Krivokhatsky, 2011.

Materials. About 50 specimens from South Russia, including type series. Additional material significantly expands the range of the subspecies. Kyrgyzstan is indicated for the first time: Kazakhstan, $1 \mathrm{~m}$, 1f, $150 \mathrm{~km}$ NE of Alma-Ata, right coast of Ili river, Mynbulak, 10.06.1988, M. Falkovich; Kyrgizstan, $1 \mathrm{~m}$ Issyk-Kul, 23.07.2018, P. Gorbunov, Photograph at Figure 22.

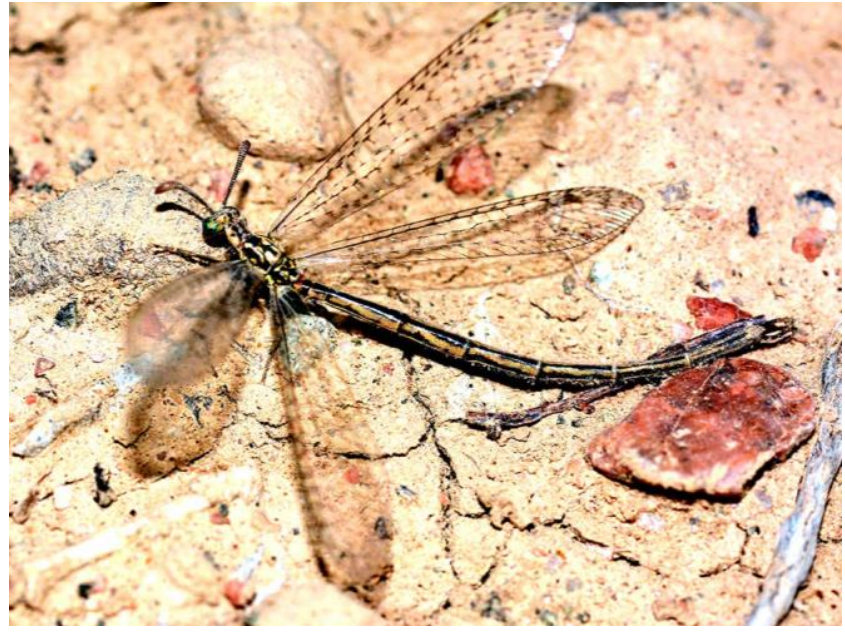

Figure 22. Mesonemurus guentheri olgae, Kyrgizstan, Issyk-Kul, 23.07.2018, Photograph P. Gorbunov.

Distribution. North-Turanian: Volgo-Uralian, Concaspian, ConAralian adventive subspecies of TuranoGobian species, which forms compact populations in sandy landscapes, and disjunctive from nominated subspecies, which contact at the Issyk-Kul area (Krivokhatsky et al. 2015). The easternmost, previously unpublished finding in Ili river basin, Mynbulak, belongs also to another, Balkhash subprovince. M. guentheri olgae is so rare and sporadic, that special trips for it catching usually were unsuccessful. Related Turan-Gobian Mesonemurus paulus (McLachlan, 1875) recorded in three fences in Low Volga.

Creoleon plumbeus (Olivier, 1811)

Syn. Creoleon plumbeus plumbeus (Olivier, 1811), Creoleon plumbeus plumbeus tabidus (Eversmann, 1841), Creoleon plumbeus remanei Hölzel, 1972

Materials. More than 300 specimens from Transcaucasia and Caucasus to Volgo-Ural and Ust-Urt regions along North Caspian shore, clockwise.

Orenburg reg., If (plumbeus), Aibulak distr., Akoba vil., 9-30.06.2013, A. Shapovalov; Saratov reg., $1 \mathrm{~m}, 1 \mathrm{f}$ (plumbeus), Diakovka vil., steppe, 25.06.2012, D. Astakhov; Rostov reg., 1f (tabidus), Voiska Donskogo Area, Zimla, 4.07.1924, Donskoe buro; Rostov reg., $2 \mathrm{f}$ (tabidus), Veshenskaya vil., steppe, 5.09.2005, E.Khachikov; Volgograd reg., $1 \mathrm{~m}$ (plumbeus), Elton Lake, river Samoroda, 15.07. 2012, D. Astakhov; Volgograd reg., $2 \mathrm{~m}$ (plumbeus), Torgun vil., river brink, 12.07.2012, D. Astakhov; Volgograd reg., $1 \mathrm{~m}, 1 \mathrm{f}$ (plumbeus), Vasilievka vil., steppe, 3-4.07. 2012, D. Astakhov; Volgograd reg., $2 \mathrm{f}$ (tabidus), Vasilievka vil., steppe, 3-4.07.2012, D. Astakhov; Astrakhan reg., $1 \mathrm{~m}$, (plumbeus), Zamjany, 22.08.2015, Mokrousov; Astrakhan reg., $1 \mathrm{~m}$, (plumbeus), Dosang vil., sands, 26.07.2012, D. Astakhov; Astrakhan reg., 2f (plumbeus), Enotaevka vil., cost of lake, 24.07.2012, D. Astakhov; Dagestan, 2 m, (plumbeus), Nogayskayia steppe, Sosnovka, 21-22.08. 2018, E. Ilyina; Dagestan, $1 \mathrm{~m}, 2 \mathrm{f}$ (plumbeus), Almalo, 25.06. 2018, E. Ilyina; Dagestan, $1 \mathrm{~m}$, 1f (plumbeus), Sarykum, 15.08. 2018, E. Ilyina; Azerbaijan, 1 m (plumbeus), Kyzylagachsky 
reserve, Kulagin state, 14.07.1998, A. Gorokhov; Azerbaijan, $1 \mathrm{~m}, 2 \mathrm{f}$ (plumbeus), Akstafa, 8.07. 1915, Satunin; Azerbaijan, 1f (plumbeus), Juga vil., 1617.09.1932, I. Rodionov; Azerbaijan, 1f (remanei), Juga vil., 18-19.08.1932, I. Rodionov; Azerbaijan, 7f (remanei), Juga vil., near Julfa, Arax river, Nakhichevan, 10.07.1932, I. Rodionov; Azerbaijan, f, (remanei), Arax river valley, 6.08.1932, N. Rjabov.

Distribution and systematics. Widespread ancient Mediterranean species inhabits deserts and steppe. Populations follow the rule of Bergman: southern ones, concentrated around the Caspian Sea, coming from Anatolia and Irano-Turan, are consisted of large pale colored straw-yellow samples, mostly similar to the type of C. remanei; northern and western ones, as well as mountain populations, probably Mediterranean origin, completed with moderate brown antlions, are typical for C. plumbeus, usually with melanistic venation. The smaller dark samples, within more northern populations, look like $C$. tabidus form. That variability is a gradient, depends on geographic location, as well as on weather conditions, therefore we ignore consider any subspecific taxa on the base of morphological features in that part of area distribution. Therefore, those three nomenclature taxa should be recognized as geographical subspecies (varieties in mixed populations) and synonyms of one species: Creoleon plumbeus (Olivier, 1811)
Creoleon tabidus (Eversmann, 1841), McLachlan, 1867: 278 (syn);

Creoleon remanei Hölzel, 1972, syn. nov.

We recognize three subspecies of $C$. plumbeus with overlapping ranges (Figure 23).

(i) C. p. plumbeus (Olivier, 1811) pale-brown medium size subspecies (a forewing of pictured specimen-32 mm), described from Greece ("Iles de l'Archipel") and distributed throughout the surveyed area;

(ii) C. p. tabidus (Eversmann, 1841) described from ConUral county (p. 359: "Habitat ad salifodinas llezkienses" 70 stadia ab urbe Orenburg" ( Sol'-Ilezk)). dark-brown small size subspecies (a forewing of lectotype$27 \mathrm{~mm}$ ). Dark smaller subspecies occupying the northern part of the specific range. Separate similar specimens can be found far from the main part of the distribution. In the previously published series of the nominative subspecies from the Volga region, there were some smaller specimens of this subspecies included (1 m, Saratov reg., Diakovka vil., at light, 9.08.1991, V. Anikin; 1f, Astrakhan Reg., Baskunchak lake, 10.08.1993, M. Volkovich);

(iii) C. p. remanei Hölzel, 1972, pale-yellow largest form (a forewing of pictured specimen-34 mm), described from Bagdad; spreading at the south-east part of the distribution area and covers the Caspian in an arc from the south and east.

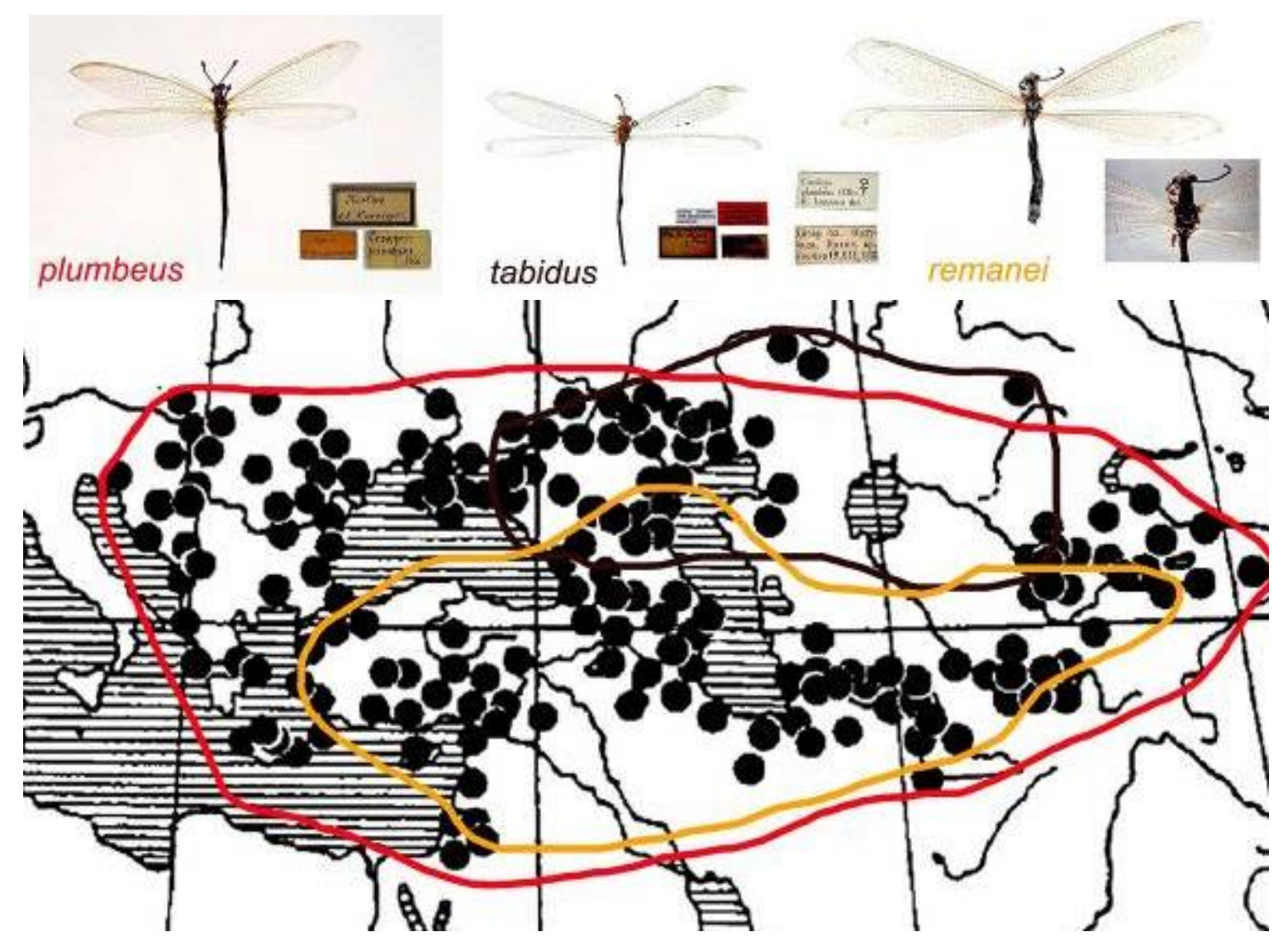

Figure 23. Creoleon plumbeus and its subspecies distribution. A. Creoleon plumbeus plumbeus (red)-male from Crimea; B. Creoleon plumbeus plumbeus tabidus (brown)-male, lectotype from Sol'-Iletzk; C. Creoleon plumbeus remanei (yellow)-female with asymmetrical anal forewing vienation from Ordubad; D. Scheme with area of distribution. Borders are colored in accordance with subspecies. 
The feature, primary (Hölzel 1972) ascribed for pale $C$. remanei, a cross vein between $2 \mathrm{~A}$ and $3 \mathrm{~A}$ in the forewing is not a specific feature, because we know a few specimens (as in Figure 23) in which its condition differs specularly (left/right wing). One specimen Creoleon plumbeus remanei with cross veins between $\mathrm{A} 1$ and $\mathrm{A} 2$ in both forewings is available only in the ZIN collection from Southern ConCaspian Area: 1f, Iran, Khorasan, ca 15 km SW Khezry Dasht-e-Bayaz, 1900 m, 33o56'N, 58043'E, 8.06. 20011, A. Timokhov.

In other hands, we have a sample completely matching the original description (e.g. cross vein between $2 \mathrm{~A}$ and $3 \mathrm{~A}$ in both forewings) and originating from a point $(1 \mathrm{~m}$, Cyprus, Paphos, Peyia vill., $34.895{ }^{\circ} \mathrm{N} 32.33111{ }^{\circ} \mathrm{E}$, 19.05.2018), at the border between typical locations of $C$. plumbeus and C. remanei.

The type series of Creoleon remanei Hölzel, 1972 represented by light specimens with transversal veins between A1 and A2 in the anal field. Later on, we collected both variants of specimens, with and without transverse veins, and specimens that were asymmetrical according to this feature were repeatedly encountered (Figure 23, remanei.). Pictured specimen [1f, Disar, near Ordubad, Nakhichevan, 19.07.1933, Znoiko, Creoleon plumbeus (Oliv.) E. Luppova det.] has transversal vein between A1 and A2 in the right anal field only. Thus, with the diagnosis of subspecies Creoleon plumbeus remanei we retain the large size and light color of the wings.

A set of these facts gives us the basis for recognizing a coherent subspecific structure of a species and for advancing an evolutionary scenario of its phylogenetic development. We propose that the ancestral form before the start of aridization in Pliocene inhabited the shores of the Tethys; it was a melanistic form, C. plumbeus, the appearance of which is preserved in most of Europe in today's temperate climate to the present time. The Eastern European and Central Palearctic Asian populations affected by Paleogene aridization, as they adapted to a rise in temperature and increased wind, acquired the appearance of larger and lighter $C$. remanei, while ancestral form $C$. plumbeus in the west and north of the region were fixed, and to the Pleistocene widely spread with the advancing steppes. At the same time, the smallest and darkest $C$. tabidus were repeatedly formed in the northern areas exposed to the effects of the advancing and retreating glaciers.

It is obvious at the distributional map of all subspecies (Figure 23), that the Caspian was located in the center of the arena of phylogenetic diversification of Creoleon plumbeus.

Euroleon nostras (Fourcroy in Geoffroy, 1785)

Materials. About 40 specimens from North Caucasian and Volga-Don regions. Kazakstan. 1 f, Dzhanybek, 13.07.2000, V.Beiko.

Distribution. West-Palaearctic nemoral species, living in the European part of Russia and known in Trans-Volga territory by few findings only (Krivokhatsky 2011; Kerimova Krivokhatsky 2018).



Figure 24. Photograph of Euroleon nostras, Nizhniaia Bannovka, ex larvi, Photograph VK

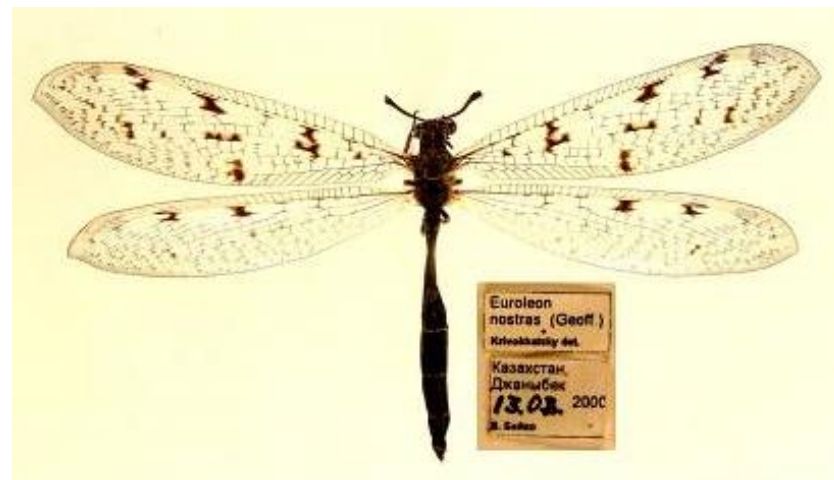

Figure 25. Photograph of Euroleon nostras, female, Dzhanybek.

At the revision of the genus (Krivokhatsky 1994), it was designated that the western ancestry form nostrasparvus, inhabiting in Miocene along the north coast of digressed Tethys, was widely spread in the northern Mediterranean during Pliocene and divided into two species allopatrically. For speciation of the Euroleon nostras-E. parvus the Prakarakum desert was the cause of barrier of isolation-, which dam conventional for Euroleon sp. biotypes: larvae of recent species avoid open sunny surfaces. Western eco genetic species are well distinguished by coloration of imago: the dark ones are Westmediterranean-Europaean nostras and the pale ones are Turanian-Middle-Asian E. parvus $\mathrm{Hz}$. In the ConCaspian territory E. nostras inhabits shaded biotopes (Figure 24) (Figure 25), larvae occupy ravines, niches, sand caves along the roads.

\section{Myrmeleon bore (Tjeder, 1941)}

Materials. About 40 specimens from North Caucasus and Volga-Ural region.

Distribution. West-Palaearctic boreo-nemoral species mainly confined to the dune landscapes at the seashores and large river banks. A safer known population exists at the river Borovka (Samara-Kinel' district) (Figure 26). Like in other parts of areal, that population subsists in the mixed colony with M. formicarius L. (Krivokhatsky 2011). 


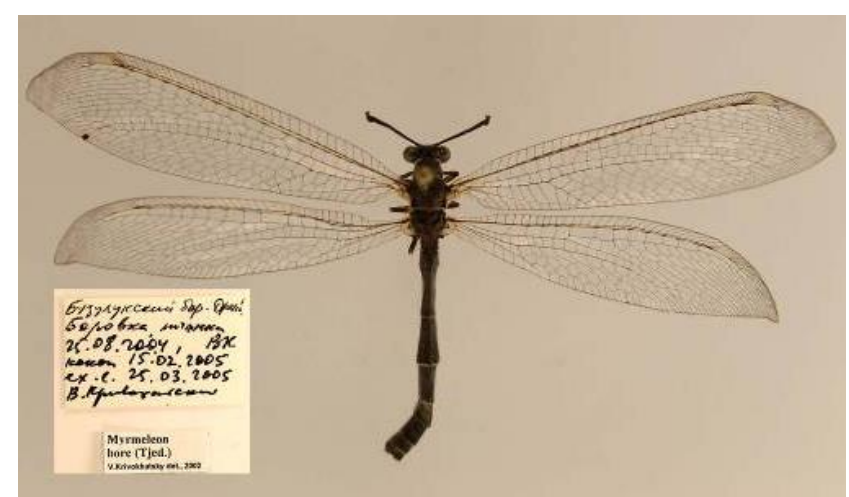

Figure 26. Photograph of Myrmeleon bore. Buzulukslyi bor, South Ural Mnt., ex larvae

In addition to this population, the species was regularly recorded in the basins of the Don, Ural and Middle Volga (Krivokhatsky and Anikin 1996; Rokhletzova 2000; Rokhletzova and Krivokhatsky 2006; Makarkin and Ruchin 2014).

\section{Myrmeleon formicarius Linnaeus, 1767}

Materials. More than 120 specimens from South Russia. Orenburg Prov., $1 \mathrm{f}, 12 \mathrm{~km} \mathrm{~W}$ of Novotroitsk, Guberlya River valley, $51^{\circ} 15^{\prime}$ N, $58^{\circ} 07^{\prime}$ E, 5.07.2018, P. Gorbunov; Saratov reg., $2 \mathrm{f}, 5 \mathrm{~km} \mathrm{~W}$ of Khvalynsk, Khrenov, $52^{\circ} 29^{\prime} \mathrm{N}, 48^{\circ} 03$ ' E, h=302 m, 4-14.07.2016, V. Anikin.

Distribution. Transpalearctic boreo-nemoral species, penetrated beyond attributable natural zones along intrazonal forest biotopes and within mountain vertical zoning. Pay tribute to precedence in first description and in width of distribution in North Palearctic, we could not get him priority in South Volga region occupation (Figure 27; Figure 28). In the north of the study area, in Mordovia, the species lives in natural conditions (Makarkin Ruchin 2014); its extremely southern populations in planted artificial forests and woodland belts are clearly brought with planting material.

The boundary of area distribution of $M$. formicarius was moved according to broad-leaved forests migrations, and has not meridional, but generally north-west direction under the influence of aridization, which begins in Central Asia in Pleistocene.

\section{Myrmeleon immanis Walker, 1853}

Materials. About 70 specimens from South Russia and adjacent territories (Figure 29).

Distribution. Scithian steppe, principally an easternpalearctic species, but is spread in a whole steppe zone of Eurasia. Larvae prefer dust soils.

\section{Myrmeleon inconspicuus Rambur, 1842}

Materials. More than 150 specimens from South Russia and Kazakhstan. Orenburg Prov., $1 \mathrm{f}, 12 \mathrm{~km}$ W of Novotroitsk, Guberlya River valley, $51^{\circ} 15^{\prime} \mathrm{N}, 58^{\circ} 07^{\prime} \mathrm{E}$, 5.07.2018, P. Gorbunov.

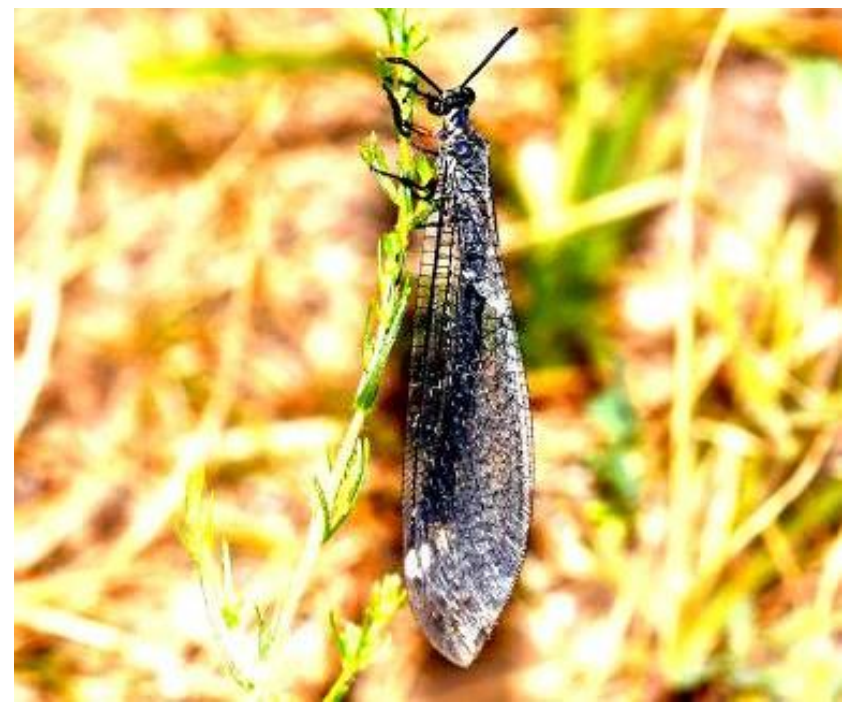

Figure 27. Photograph of Myrmeleon formicarius, Kazakhstan, Dzhuanaryk, Photograph P.G.



Figure 28. Photograph of Myrmeleon formicarius. Buzulukslyi bor, South Ural Mnt., ex larvae.

Distribution. Eurasian nemoral-steppe species with center of area distribution in Volga region, where last century maximal abundance has registered. Larvae inhabit predominately in sandy soils, preferring the shade of trees and shrubs (Krivokhatsky Zakharenko 1996). It has been shown that numerous finds of this nemoral and other forest and steppe species of the genus Myrmeleon in the Northern Caspian region belong to interzonal and oasis areas (Krivokhatsky Piryulin 1997) (Figure 30; Figure 31).

\section{Aspoeckiana uralensis Hölzel, 1969}

Syn. A. uralensis uralensis Hölzel, 1969; A. uralensis curdica Hölzel, 1972; A. uralensis jakushenkoi Zakharenko, 1983; A. uralensis longiventris Zakharenko, 1983

Materials. About 80 specimens from North Caspian Russia and adjacent territories. 


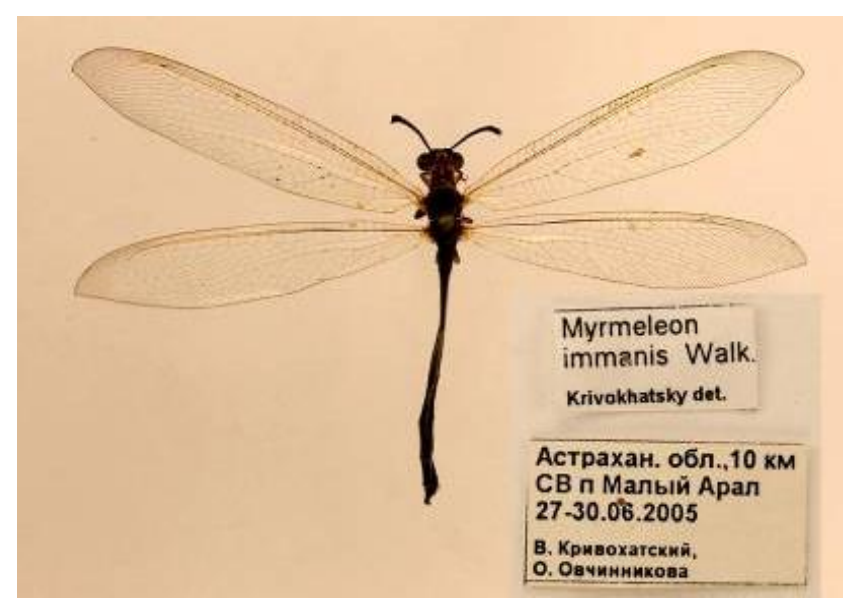

Figure 29. Photograph of Myrmeleon immanis, female, Astrakhan Reg.



Figure 30. Photograph of Myrmeleon inconspicuous, reared from larvae in Nizhnyaia Bannovka, Photograph VK.



Figure 31. Myrmeleon inconspicuous, male, Volga river, Khomutinskyi Island, Middle Volga.

Russia. Kalmykia, $1 \mathrm{~m}$ (21750), $1 \mathrm{f}$ (21747), (A. $u$. uralensis), $45 \mathrm{~km}$. Elista, 18.08.1990, A. Zakharenko; $1 \mathrm{~m}$, (A. u. uralensis), Chernozemelsky district, $5 \mathrm{~km} \mathrm{E}$ settlement Andratinsky, sands, river Kuma; Astrakhan region, $1 \mathrm{~m}, \quad(A . \quad$. uralensis), Lake Baskunchak, larvae.10.06.03, cocoon 15.07.03, ex.1.25.08.2003, V.Krivokhatsky; $1 \mathrm{~m}$, (A. u. uralensis), River Akhtuba, railway station Dosang, 6.09.1966, L. Pritykina; $1 \mathrm{~m}$, 1f (A. u. jakushenkoi), river Akhtuba, rail station Dosang, 6, 10.09.1966, L. Pritykina; $1 \mathrm{~m}$, (A. u. uralensis), Vladimirovka, 24.7.1930, Artemy Popopov;

Kazakhstan. Uralsk reg., $1 \mathrm{~m}, 1 \mathrm{f},($ A. u. uralensis), 10 km NE of Aral-Sor vil., 11.08.1990, V. Krivokhatsky; 2 m, $10 \mathrm{f}$ (A. u. uralensis), $10 \mathrm{~km}$. W. Novaya Kazanka [Zhanakazan], steppe, 12.08.1990, Krivokhatsky, Zakharenko; 1 m,-6 m (A. u. uralensis), Uralsk reg., 20 km. W. Kalmykovo, steppe, 12-13.08.1990, Krivokhatsky $1 \mathrm{~m}$ (A. u. uralensis), Uralsk reg., $45 \mathrm{~km}$. W. Kalmykovo (21694) 13.08.1990, A. Zakharenko; West Kazakhstan region, $2 \mathrm{~m}$ (A. u. uralensis), $40 \mathrm{~km}$. W. Kalmykovo [Taypak], sands, 12-13.08.1990, Krivokhatsky, Zakharenko; West Kazakhstan region, $1 \mathrm{~m}$ (A. $u$. uralensis), Dzhanybek, 17.08.2000, V. Beyko; Atyrau region, $2 \mathrm{~m}$ (A. u. uralensis), Lake Inder, NE northeast coast, 6.08.1993, M.Volkovich; 4 m, (A. u. uralensis), village Inder, coast of the river Ural, 14.08.1990, Krivokhatsky, Zakharenko; Guriev (Atyrau) province, 1f (A. u. jakushenkoi), vill. Inder, bank of the river Ural, 14.08.1990, Krivokhatsky, Zakharenko; 3f (A. $u$. uralensis), Atyrau region, village Makhambet, coast of the river Ural, 14.08.1990, Krivokhatsky; $1 \mathrm{~m}$ (A. u. uralensis), 50 km., E. Ganyushkino [Kurmangazy], sands, 15.08.1990, Krivokhatsky; $1 \mathrm{~m}$ (A. u. jakushenkoi), 50 km., E. Ganyushkino (Kurmangazy), sands, 15.08.1990, V. Krivokhatsky; Atyrau region, 2f (A. u. uralensis), $50 \mathrm{~km}$., NW Akkystau, 15.08.1990, Krivokhatsky; $1 \mathrm{~m}$ (A. $u$. jakushenkoi), 90 km., Akkystau, 15.08.1990, Krivokhatsky; 1f (A. u. jakushenkoi), 50 km., NW Akkystau, 15.08.1990, Krivokhatsky; 1f (A. u. jakushenkoi), close Sarykamys, 1.08.1993, M. Volkovich; $1 \mathrm{~m}$ (A. u. uralensis), Balkkuduk, 10.07.1991, P. Romantsev; Mangistau region, 1f (A. u. uralensis), $10 \mathrm{~km}$. of Beyneu, 30-1.07.1993, M. Volkovich; Aktyubinsk reg., $1 \mathrm{~m}$ (A. u. uralensis), Chelkar [Shalkar], larva collected 27.05.2006, ex larvi 19.07.2006, V. Krivokhatsky.

Azerbaijan. $1 \mathrm{~m}$ (A. uralensis curdica), Tatoni (Zuvant), Lenkoran distr., 04.08.1932, M. Ryabov; [Nakhichivan], $7 \mathrm{f}$ (A. uralensis curdica), Araks, Syurtyui picket, № 1 near Dzhugha, 3-4.09.1932, M. Ryabov; 1f (A. uralensis curdica), Araks, Syurtyui picket, № 1 near Dzhugha, 45.09.1932, M. Ryabov; $1 \mathrm{~m}$ (A. uralensis curdica), Nakhichivan, Darasham I, near village Dzhuga, 25.08.1932, I. Rodionov; $1 \mathrm{~m}$ (A. uralensis curdica), Dzhugha, near Dzhulfa, river Araks, 8.09.1932, I. Rodionov.

Distribution. Turano-Gobian species, nominative subspecies described from Uralsk (Conuralian district). Aspoeckiana uralensis is variable species with five described subspecific taxa with overlapping areas of distribution. In the North Caspian region of Russia 2 subspecies have been recorded; some eastern, in ConAral region 4 subspecies were registered (Krivokhatsky Piryulin 1997). However, every subspecies has own preferable area. Rather more northern among others, North-TuranianVolgo-Uralian, A. uralensis uralensis Hz., occurs from 
Kalmykia to North Aral Sea coast and Balkhash Lake via middle Ural river plane; it was indicate from this area (Krivokhatsky Piryulin 1997), but specimens from ZIN collection listed only above and here (Kyzyl-Orda region, 1f, $1 \mathrm{~m}$, Aral Sea, Barsakelmes Island, 24.08.1973, 10.07.81, D. Piryulin; Zhambyl region 2f, Railway station Timur, Orenburg-Tashkent, 50 versts S of Turkstan, Klare, 5.06-11.009.1903; Zhambyl region 1f, Aulie-Ata [Zhambyl akimat], 3.08.1909, A.Nerovetsky; Almaty, 1f, ravine Bolshoe Almatinskoe, 5.08.1969, A.Emelyanov; Almaty region, 1f, $10 \mathrm{~km}$ above the village Charyn, 10.03.1969, A.Emelyanov; Almaty region, $1 \mathrm{~m}$, E Zailiyskiy Alatau, mountains Syugaty, W of Charyn, 08.08.1969, Emelyanov). Nominative subspecies has also eastern Turkestano-Gobian separate part. Indications for Kirghizia and Tajikistan here (Kirghizia, $1 \mathrm{~m}$, south shore of the lake Issyk-Kul, Kadzhi-Say, 1620 m., 20.07.1992, V. Lukhtanov; Tajikistan, $1 \mathrm{~m}$, Khorog, Shashin.Dasht, botanical garden, h-2200, summer 1970, E. Andreeva) are given for the first time. First record for India (1 m, R.Vani Kk Gujovast, dry slope, 25.07. 1961, V. Popov; 1f, R.Vani, Kk Gujovast, 01.08.1961, V. Popov) unexpectedly.

Aspoeckiana uralensis jakushenkoi was described from Central Kazakhstan (Zakharenko 1983), characterized as North-Turanian (Krivokhatsky 2011) and later the south western border of the range of A. u. jakushenkoi continues along the coast of the Caspian Sea to the mouth of Kuma River, Dagestan, and to Siyazan, Azerbaijan (Kerimova and Krivokhatsky 2018). Some collections of subspecies from ConCaspian Kazakhstan (Shalkar, Aral-Sor, Ryn sands) recorded in previous paper (Krivokhatsky et al. 2016), others added here. Data on Turkmenistan $(1 \mathrm{~m}$, Badkhyz, Kyzyl-Jar, sands, 25-26.08.1990, Krivokhatsky; 1f, Molla-Kara,at light,12,09.1933,Ya.Vlasov) and Uzbekistan (1 m, Xorazm distr., Khiva, Ravat, 29.07.1927, V. Gussakovsky; 2 m, Zhamansai, Kyzylkum, 20.08.1970, Falkovich; 1f, Ayakguzhumdy, $40 \mathrm{~km} \quad \mathrm{E}$ of Jingeldy,.Kyzylkum, 09.09.1971, Falkovich; $1 \mathrm{~m}$, Mountains Kuldzhuktau, Kyzylkum, 12.09.1971, Falkovich; 1f, Namangan distr., Chust, 4.09.1928, L. Bianki) recorded for the first time. Almost collecting data from ZIN from Central Kazakhstan (Aktjubinsk reg., 3f, Chelkar [Sholkar], Big Barsuki desert, Turg. 1112.08.1933, Luppova; Aktjubinsk reg., 1 specimen without abdomen, sex unknown, Chelkar [Shalkar], on a lamp, 20.07.1930, A. Kozhev; Kyzyl-Orda region, 21f, 3 m, Aral Sea, Barsakelmes Island, 09.08.1977, 10.07.81, 22.08.1981, 20.08.1982, 15.09.1982, 9-10.07.1992, 2224.07.1992, D. Piryulin; Kyzyl-Orda region, Takyr-kuduk, 1f, ConAral Karakumy, at light, Luppova, 08.18.1930; Kyzyl-Orda region, Karakayli-Naiman, 1 m, Ak-kuduk, ConAral Karakum, 08.13.1930, Luppova; Zhambyl region 2f, Maituba, Baikonur (Karatau range, $24 \mathrm{~km}$ of Karatau city, 2.07.1913, Anonym; Zhambyl region 2f, Railway station Timur, Orenburg-Tashkent, 50 versts $\mathrm{S}$ of Turkstan, Klare, 5.06-11.09.1903; Zhambyl region, 1 demaged specimen, sex unknown, Mujun-Kum desert, 16.08.07, Baeckmann; Almaty region, 1f, ravine Bolshoe
Almatinskoe, 5.08.1969, A.Emelyanov; Almaty region, 1 $\mathrm{m}$, 1f, $15 \mathrm{~km}$ below the of Bakanas along Ili river, 2.08.1969, D. Emelyanov; Almaty region, 1f, $100 \mathrm{~km}$. N Iliysk [Kapshagai], sandy desert, Mityaev; Karaganda reg. $4 \mathrm{~m}, 1 \mathrm{f}$, Balkhash district, village.Bakh-Bahty, 09.08.1981, 13.08.1981, paratypes of A. uralensis jakushenkoi Zakharenko; Karaganda reg., 1 m,1f, Balkhash district, near village Karagach, 05.08.1981, 07.08.1981, 12.08.1981, paratypes of A. uralensis jakushenkoi Zakharenko; Mangystau reg. $1 \mathrm{~m}$, Beke, Mangyshlak river, Grunin, 7.08.1955) included to the map (Figure 32).

Aspoeckiana uralensis jakushenkoi, North-Turanian subspecies, but some southern than A. uralensis uralensis, distributed in disjunctive parts: in North-East Caucasus with adjacent Kalmykia, in Northern Concaspian shore, in Kyzylkum desert, Con-Aral territory and in Con-Balkhash shore. We view these sites as places of contemporary evolutionary processes.

Predominantly South Turanian A. uralensis longiventris was not registered in the ConCaspian Shore (Krivokhatsky et al., 2016; Kerimova and Krivokhatsky, 2018), but noted in the Aral Sea region without indication of specimens localities (Krivokhatsky, Piryulin 1997). Therefore it was firstly recorded here for Kazakhstan (Kyzyl-Orda reg., 3f, Sands Baygana, ConAral Karakumy, 15-22.08.30, Luppova; Kyzyl-Orda reg., 1f, Aral Sea, Barsakelmes Island, homestead, 24.07.83, D. Piryulin; Kyzyl-Orda reg., $2 \mathrm{~m}, 1 \mathrm{f}, 1$ specimen with broken abdomen, rail station Kazalinsk and Tjura-Tam, 12.08.1960, Yu.L.Chen; Akmola reg., $1 \mathrm{~m}$, Leninsk, 15.07.1980, paratypes of $A$. uralensis jakushenkoi Zakharenko), Uzbekistan ( Vrevskaja, 3f, pr.Tashkent, O.Tshernova, 1929; 2 m, 1f, 1 sample, sex unknown, Zhamansay, Kyzylkum Uzbekistan, 20.08.70, Falkovich; $1 \mathrm{~m}$, Zhamansai, Kyzylkum Uzbekistan, 20.08.70, Falkovich; 2f, 1 m, Ayakguzhumdy, $40 \mathrm{~km}$ E of, Dzhingilda, Uzbekistan, 31.08.69, Falkovich; 1f, Ayakguzhumdy, $40 \mathrm{~km}$ E of Dzhingildy, 09.09.68, Falkovich; ), Tajikistan (Tigrovaya Balka, $1 \mathrm{~m}$, lower Vakhsh, at light, 2.09.1953, E.Luppova) and Monglia (2f, China, river Tsagan-gol, northwest Monglia, 1.08.98, Clementz). That taxa was described from Turkmenistan (1 m, Bayram-Ali, 22.08.1929, B. Rodendorf, paratypes of $A$. uralensis longiventris Zakharenko No. 10110) and we present here a new localities of $A$. uralensis longiventris from ZIN collection (1 m, Neftezavodsk, 29.08.1990, G. Davidyan; Repetek, 1f, 11.09.1907, Pelz; 1 m, Ashgabat, district, 31.08.1932, Ya.Vlasov; 1f, Badkhyz, Kyzyljar, steppe, 25-26.08.1990, Krivokhatsky).

Irano-Kura-Araxian Aspoeckiana uralensis curdica separate from A. uralensis jakushenkoi in Caucasian coast (Kerimova and Krivokhatsky 2018). In the East, in Iran at Kopet-Dagh (Mirmoayedi et al. 1999) A. uralensis curdica verge on $A$. uralensis longiventris. Some specimens from ZIN collection (Dzhuga on Arax river, August-September, 1932, I. Rodionov) published previously (Kerimova and Krivokhatsky 2018), other remains from Azerbaijan listed above in the present essay. 




- curdica

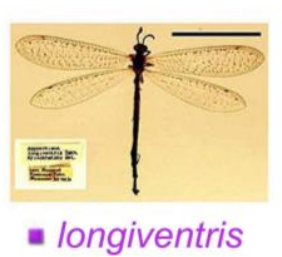

- longiventris
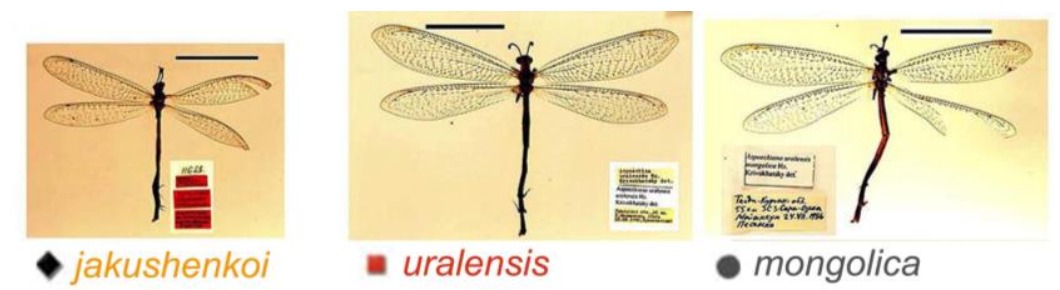

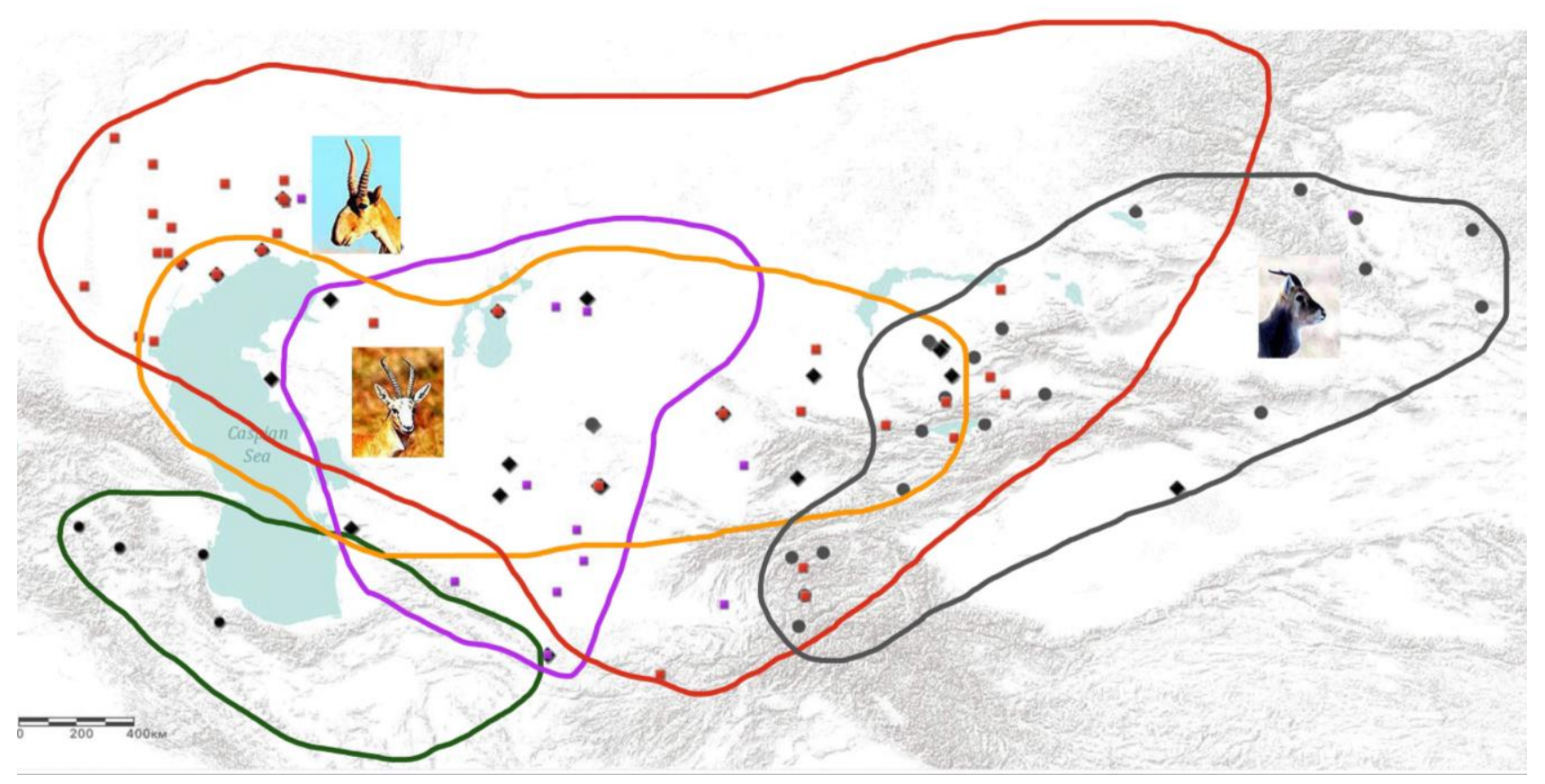

Figure 32. Aspoeckiana uralensis and it subspecies distribution in connection with the spread of antelope. ๑: Aspoeckiana uralensis curdica Hölzel, 1972, male, Nakhichivan; 口: Aspoeckiana uralensis longiventris Zakharenko, 1983, male, Kyzylkum desert, Uzbekistan; -Aspoeckiana uralensis jakushenkoi Zakharenko, 1983, paratype, male, Balkhash lake, Kazakhstan; $\mathbf{\square}:$ Aspoeckiana uralensis uralensis Hölzel, 1969, male, Taypak sands, Kazakhstan; ○. Aspoeckiana uralensis mongolica Hölzel, 1970, male, Moiynkum desert, Kazakhstan. A. Collecting specimens of antlions. Scale-10 mm. B. Scheme with area of distribution. Borders colored in accordance with subspecies. Spreading area of antelopes: 1. Saiga tatarica; 2. Gazella subgutturosa; 3. Procapra gutturosa

Widespread in Mongolia (Hölzel 1970) A. uralensis mongolica pointed in the map of Mongolia with noting from Kazakstan and Middl Asia without listing of real localities (Krivokhatsky et al. 1996). Consequently, data of ZIN collection are new, and Kazakhstan (2 m, Almaty reg., Kyzyl-Agach, Semirechye province, Kopal district, N.Chetvertkov 30.07.1910; $1 \mathrm{~m}$, Semirechye, 1902, Sapozhkov; 2f, Karakol, 14.07.1999, A. Zhdanko; Lake Zaisan, 1f, near the White School, at light, 25.07.1978, anonym; 2 m, 2f, Taldy-Kurgan.obl., 55 km.WNW SaryOzsk, Moyynkum, 24.07.1986, Pesenko; 4 m, 1f, 15 km Lower Bakhanas along the Ili river, 2.08.1969, A. Emelyanov; 2 m, 3f, 2 ex., sex unknown, Chelkar [Sholkar], 20.07.1930, A. Gozhev), Kyrgyzstan (1f, Ortotokoi, 20-22.07.1997, V.Dolin; 2f, Valley river Arna, tributary of the river Acha, to the NW from the lake Chatar-Kol, 16.08.1971, Tarbinsky; 1 m, Jalal-Abad reg., Foothills of Uzun-Ahmad, near Ketmen-Tyube, 09.08.1930, L. Bianki), Tadjikistan (Pamir, 1f, Khorog, botanical garden, at light, 18-21.08.1962, V.Sychevskaya; 1f, № 214-1901, Khorog. Fedchenko; 1f, Khorog, botanical garden, 1-4.09.1984, V. Mikhailov; $1 \mathrm{~m}$, 1f, 13.Pamir, Khorog, 20.08.1936, A. Ivanov; 2 m, 1 ex., sex unknown, Gorno-Badhshan Autonomous Region, 01.08.1958, K. Gorodkov, + second label: $10 \mathrm{~km}$. $\mathrm{N}$ of the end of the Fedchenko Glacier, valley river Kaindy, 3000 m.; 1f, Gorno-Badahshan Autonomous Region, $10 \mathrm{~km} . \mathrm{N}$ of the end of the Fedchenko Glacier, valley river Kaindy.3000 m., 19.08.1958, Gorodkov), Afganistan (1 m, Badakshan, No, Zebuk 2800,20.07.1973., O. Kabakov) and China (1f, Astyna, S Turfan, Chinese Turkestan, 16.09.1898, Klements) recorded for the first time.

ZIN collections from Mongolia are: 1f, North-West Mongolia, Muryk near Ulya-sutay, 20.08.1977, Potanin; 1f, Kobdoskiy aymak. river Ulistine-Gol, $25 \mathrm{~km}$. NW Bulgan, 31.07.1970, I. Kerzhner; 1 m, Kobd.aimak, Ulyasutak-Gol river, 25 km. N Bulgak, 30.07.1970 I. Kerzhner; 4 m, Hovd.aymak, south slope Mongolian Altai, Lower 
Bodonch-Gol, 17.07.203, P.Ustyuzhanin; 2f, Hovd.aymak, south slope Mongolian Altai, Lower Bodonch-Gol, 17.07.203, P.Ustyuzhanin; 2 m, 1f, Gobi-Altai aimak, 25 $\mathrm{km}$. N Somon Beger, creek valley, at light, 26.06.1999, P. Ustyuzhanin, from collection of the Siberian Zoological Museum, Novosibirsk.

Divergence of concaspian subspecies, southturanian $A$. uralensis longiventris Zakh., and mongolo-gobian $A$. uralensis mongolica Hz. from Oligocene to Pliocene has been proposed (Krivokhatsky 2009).

Larvae of $A$. uralensis in Volga-Ural interfluve colonized the trampled ground on the pathways of Saiga tatarica L., and mass flight activity has been registered in the rest landings of flocks of saiga antelope close to village Novaya Kasanka (Zhanakazan) and Kalmykovo (recently Taipak) at the end of XX century. Aspoeckiana uralensis uralensis cohabited with the saiga antelope, using their paths for larval colonies.

Thus, we determine coincidence of areas of distribution of two taxa Saiga tatarica tatarica L. and Aspoeckiana uralensis uralensis $\mathrm{Hz}$. in details. The areas of $A$. uralensis uralensis and $A$. u. jakushenkoi supported with different populations of saiga, as well as other subspecies depend on the distribution of related antelopes: South-Turanian Aspoeckiana uralensis longiventris depends on gazelle (Gazella subgutturosa Guldenstaedt, 1780) and Aspoeckiana uralensis mongolica-on dzeren (Procapra gutturosa Pallas, 1777). They were separated in Pliocene. Caucasian subspecies Aspoeckiana uralensis curdica much probably the youngest (Pleistocene) subspecies associated in its appearance with small livestock, sheep (Ovis orientalis aries Gmelin, 1774).

Usually in series, collected in the same time in the same locality, the specimens are determined as only one subspecies. Previously (Krivokhatsky 2011) there were two series only (Stavropol reg., Barsakelmes Island in the Aral Sea), where few samples of rare taxa admixed to dominant subspecies. Last records of $A$. uralensis jakushenkoi inside of population nucleus of $A$. $u$. uralensis (Krivokhatsky et al. 2016) would have us believe that populations of ConKumian fence and Ryn Desert are safely and in good heterozygote condition.

Lopezus fedtschenkoi (McLachlan, 1875)

Syn. Lopezus fedtschenkoi morpha typica; Lopezus fedtschenkoi morpha maclachlani Krivokhatsky, 1990

Materials. About 50 specimens from Volga Region and Con-Caspian shore. Kazakhstan, 1f (morpha typica), Atyrau Reg., North Caspy, Ysatai vil., 29.05.2013, I. Matyukhin, in alcohol (Figure 33; Figure 34; Figure 35).

Distribution. Sakharo-Gobian species, widespread from Tunisia to Mongolia. Variable superspecies, which includes local populations, consistent from identical samples, as well as volatile populations, where different morphs present as well as specimens, classified, as different geographical subspecies (Krivokhatsky 1990, 2011). At many places in Turano-Gobian area, there is the most abundant species among antlions. In Volga region and North Caspian shore that species inhabit sandy and clay desert landscapes, ordinary in some localities.

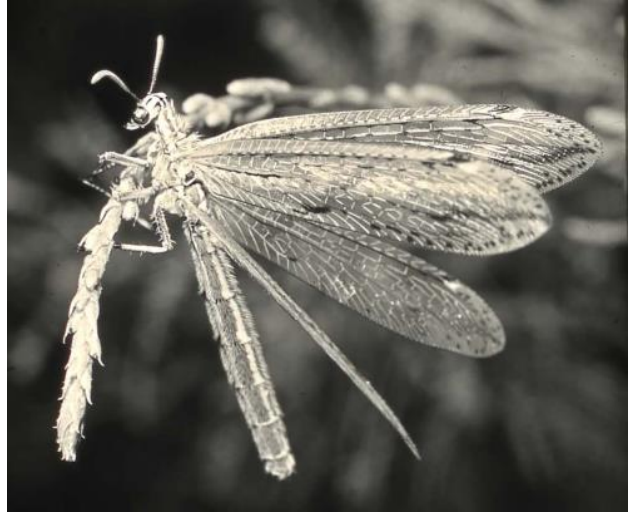

Figure 33. Lopezus fedtschenkoi, Barsakelmes Island, Aral Sea. Photograph D.P.



Figure 34. Lopezus fedtschenkoi McL., female from Urda, morpha typical

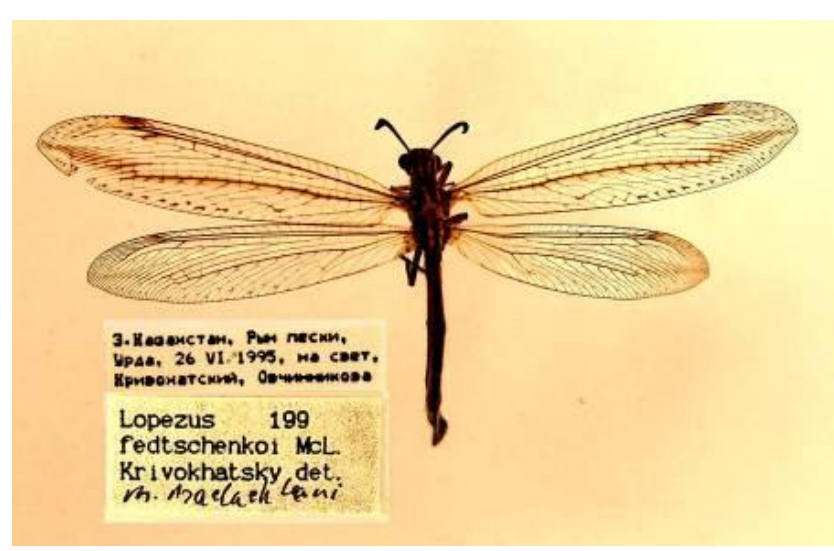

Figure 35. Lopezus fedtschenkoi McL., female from Urda, morpha maclachlani Kriv.

The population in Ryn desert (26f, West Kazakstan, Urda, 26 VI 1995, Krivokhatsky, Ovtshinnikova) compiled probably from parthenogenetic females only, though probably males have a more short time of flight, and at the end of June here only females present. In mentioned population (26f. Urda, Ryn desert) the most specimens (21f) belong to the typical morph, but five ones (5f)-to the black-striped morph maclachlani. In natural safe bisexual 
populations (Zakhmet, Karakum desert) the relation between specimens of different morphs is 1: 1. In Caspian and ConVolgians populations the typical morph has prevailed, and in many fences, black-striped morph repressed wholly. The decrease of population heterozygosity could be explained with edge effect as well as with the decline in ecological standards.

\section{Myrmecaelurus trigrammus (Pallas, 1771)}

Materials. More than 1500 specimens from South Russia and adjacent regions. Orenburg Prov., $3 \mathrm{~m}, 12 \mathrm{~km}$ W of Novotroitsk, Guberlya River valley, $51^{\circ} 15^{\prime}$ N, $58^{\circ} 07^{\prime}$ E, 5.07.2018, P. Gorbunov.

Distribution. Widespread ancient Mediterranean species inhabited the flat steppe. Appears that $M$. trigrammus has been more characteristic species among antlions of the south of Russian plain. As an element of concrete faunas it presents in every cluster in every dendrogram. Species-area distribution in West and central Palaearctic covers steppe zone and uses steppe, desert and meadow bridges for penetration into other natural zones and anthropogenic disturbed landscapes (Figure 36; Figure 37).

Species was described from Transvolga plain (Pallas 1771), where subsequently population of terra typica has been safe and numerous (Krivokhatsky 2011). Last century the area of distribution has been reduced at the expense of elimination on the plains of Kazakhstan and Middle Asia due to Con-Aral anthropogenic salinization (Krivokhatsky Piryulin 1997). Another negative factor is overgrazing. At the localities, where negative factors missed long time the population nuclei could forming, which ensure safe species itself. At the beginning of XXI century, such nuclei were situated in Crimea (Karadagh, Kazantip), in Dagestan (Sarykum), in Astrakhan reg. (Barkhannyi. Nikol'skoie), Volgograd reg. (Dubovka, Dzhanybek), Samara reg. (Samara Luka), Saratov reg. (Nizhniaja Bannovka).

The nearest Iranian-Turanian relative of this species, Myrmecaelurus solaris Krivokhatsky, 2002, densely borders with it in the region of arid Transcaucasia, and in the desert-steppe area, they share different forms of relief. If $M$. trigrammus is more common species in Russian ConCaspian territory, $M$. solaris can be recognized as its substitute in the composition of Transcaucasian-fauna.

\section{Myrmecaelurus major McLachlan, 1875}

Materials. More than 30 specimens from Volga Region and Caucasus.

Distribution. Mainly East-Mediterranean-NorthTuranian species inhabit desert fences, where originated under the influence of North Turan on the north of investigated territory and under the influence of IranoAnatolian fauna in the south. Temperate plain species ancestry M. major (Figure 38; Figure 39) is separated from semi-subtropical submontane $M$. paghmanus $\mathrm{Hz}$. at the period of landscape-climatic divergence of North and South Turan in Pleistocene (Krivokhatsky 2009). The rarest species among representatives of the genus in the Caspian fauna $(1,2)$, only in Kalmykia, where it lives together with M. trigrammus, occurs relatively in mass (3).

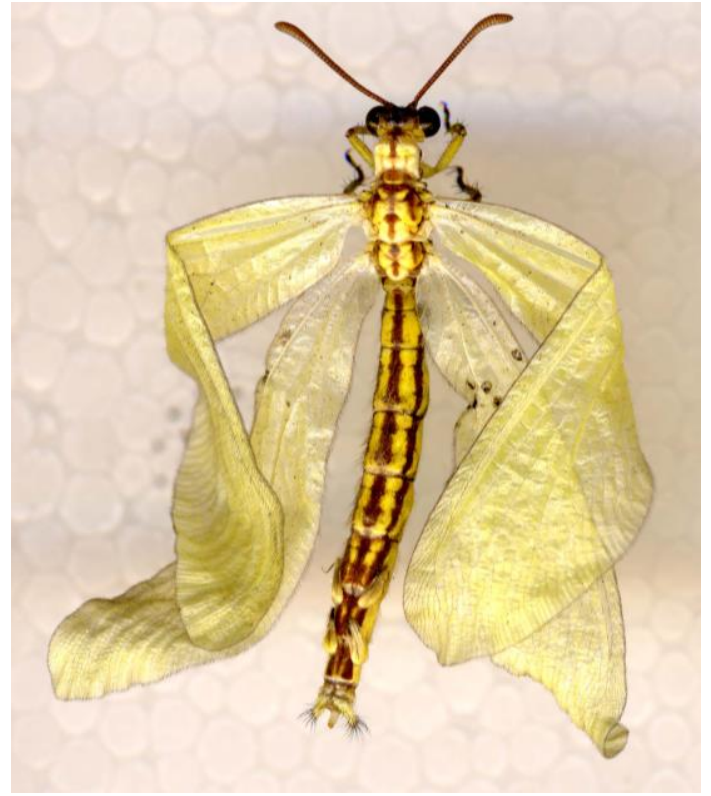

Figure 36. Myrmecaelurus trigrammus, reared from larvae in Nizhnyaia Bannovka, Photograph V.K.

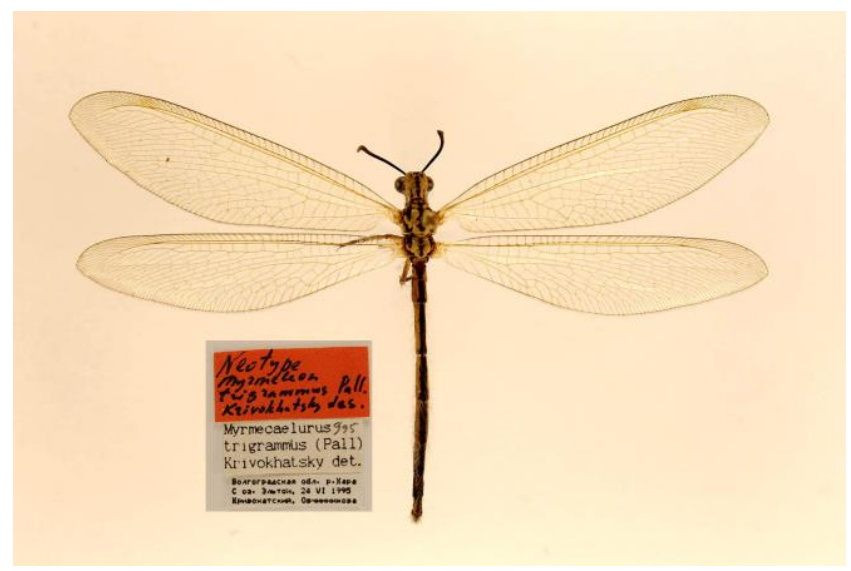

Figure 37. Neotype of Myrmecaelurus trigrammus (Pall.), male, from Elton Lake.

Nohoveus zigan (Aspöck, Aspöck et Hölzel, 1980)

Materials. About 80 specimens from Volga-Ural Region and along Caspian shore.

Distribution. Extremely steppe species with wide south-Scythian-the north-Turanian type of distribution. In addition to the known distribution (Krivokhatsky 2011), we record here the northern locality of $N$. zigan from UralTobol interfluve $(1 \mathrm{~m}, 1 \mathrm{f}$, on the way from Toguzak to River Kal'blir (Kazakhstan, Kostanai Region), No. 39, 27.06. (1939), A.G. Bartenev, ZIN).

The population variability follows with rule of Bergman: at the northern deserts, in Concaspian sands, as example, 1 m, 3 f, Malyi_Aral, 10 km E, 7.06.1991, V. Krivokhatsky (Figure 40), more small and bright specimens have been registered, as well as in southern Azerbaijanian Caspian Sea shore, 9 m, 5 f, Siazan, 3.08.2017, I. Kerimova (Figure 41) lightly doted large specimens were fined. 


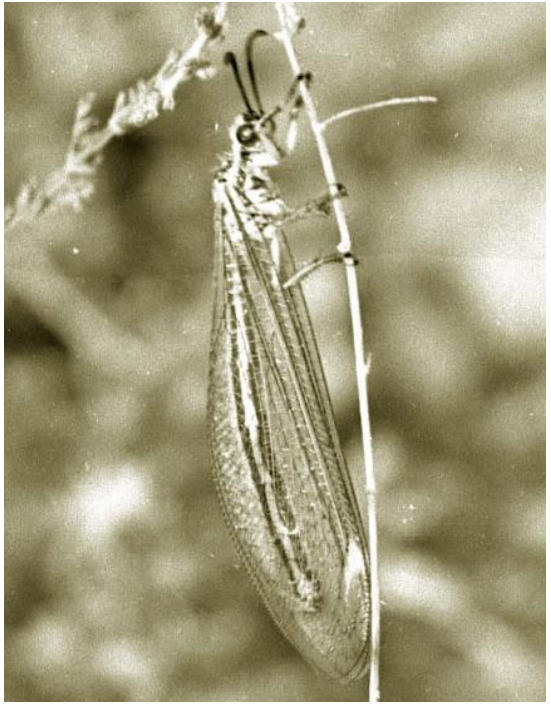

Figure 38. Myrmecaelurus major Barsakelmes, Photograph D.P.

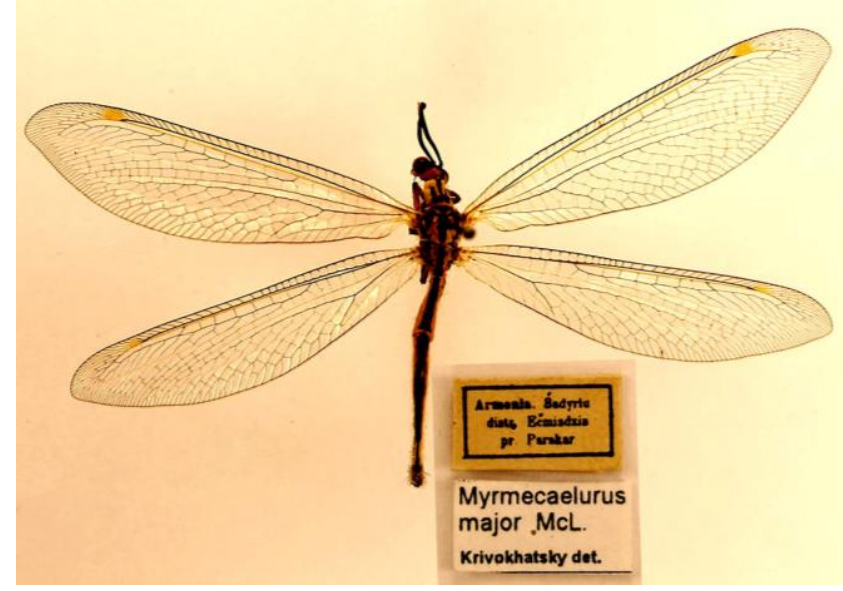

Figure 39. Myrmecaelurus major Echmiadzin, Armenia



Figure 40. Nohoveus zigan, male, from Elton vill.

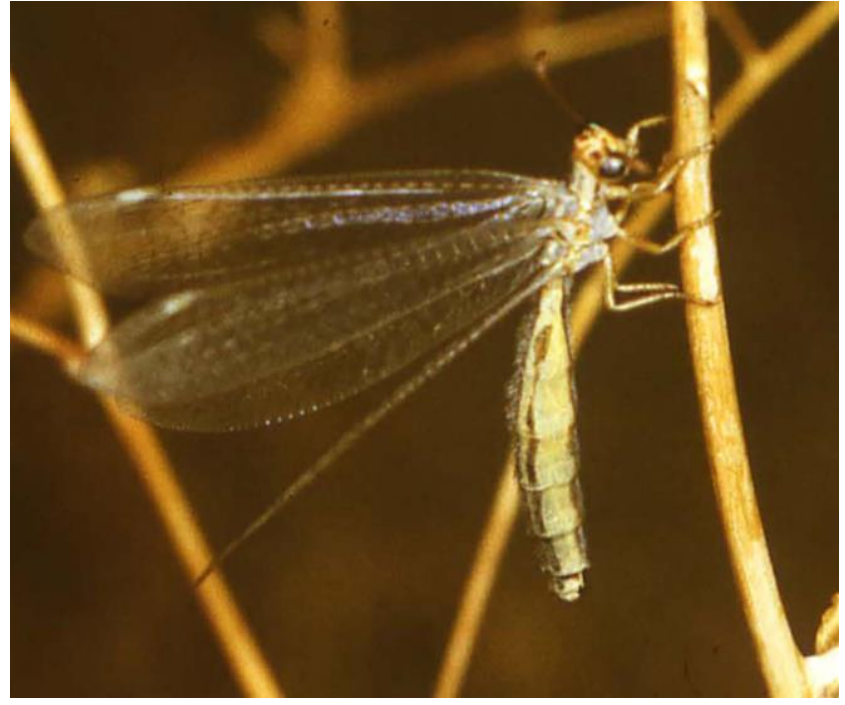

Figure 41. Nohoveus zigan, female, Siazan, 3.08.2017, Photograph I.K.

In the related group of species Nohoveus zigan sp. gr., in addition to the nominative widely-represented, we took into account the species found only in Transcaucasia the Nohoveus armenicus (Krivokhatsky 1993) characteristic for the Transcaucasian (TC) concrete fauna. The wide geographic disjunction of the pair Nohoveus zigan-N. armenicus in the Caucasus was discussed previously (Kerimova and Krivokhatsky 2018). At the same time $N$. zigan almost completely sympatric with $N$. atrifrons Hölzel, 1970, (the nearest relative of $N$. armenicus) in the Sethian part of the $N$. zigan range. Recent distribution of the group allows us to assume independent evolutionary scenarios for taxa $N$. zigan and $N$. atrifrons $+N$. armenicus and accordingly the order of their speciation. The melanistic $N$. zigan could separate from pale sister group $N$. atrifrons $+N$. armenicus as a result of ecological isolation within common range, choosing meadows and wet steppe, while sister group of pale $N$. atrifrons $+N$. armenicus inhabits dry steppes and semideserts in the period of aridization. The geographical isolation of the northern $N$. atrifrons from the southern $N$. armenicus (differ from each other by the tracery pattern of head) had been completed in the next step of evolution.

\section{Cueta anomala Navás, 1915}

Materials. 4 females from Dagestan only (Figure 42).

Distribution. That species with the wide Kura-AraxianAnatolian distribution comprehends North Caucasus with the northern part of its areal only (Trsko-Sunzhen fence) and occurs in Russia sporadically (Krivokhatsky 2011). To the cluster analysis the other species, Cueta lineosa Rmb., was included. It was not known from Russia, but inhabits North Caspian area in Kazakhstan, coming through Usturt to the River Emba close Kulsary. 


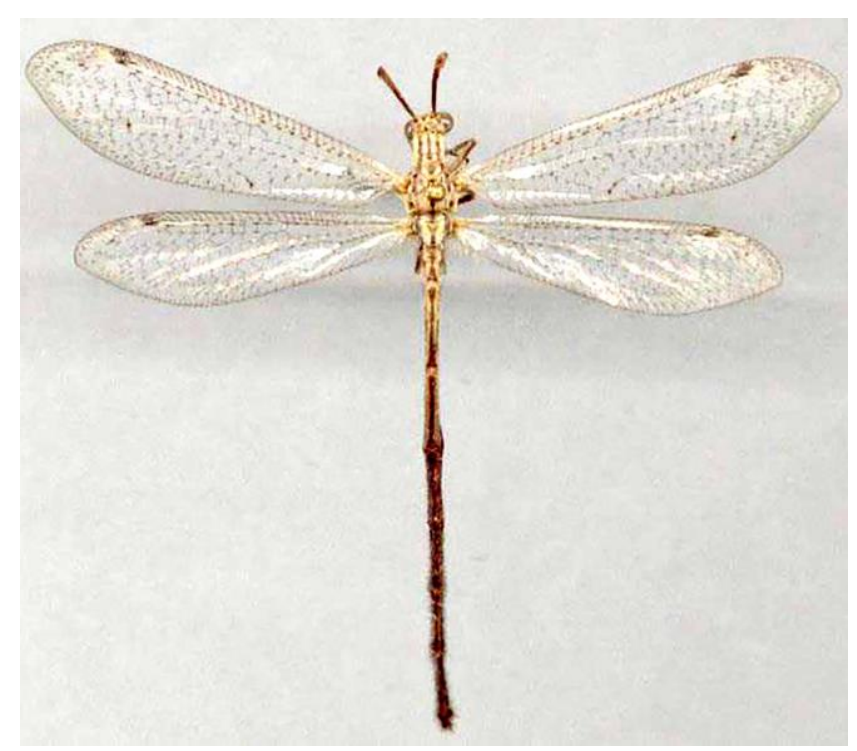

Figure 42. Cueta anomala



Figure 43. Acanthaclisis occitanica

Acanthaclisis occitanica (Villers, 1789)

Syn. Acanthaclisis occitanica morpha typica; Acanthaclisis occitanica morpha nigrilenta Krivokhatsky, 2005

Materials. More than 120 specimens from South Russia and adjacent regions. Dagestan, $1 \mathrm{f}$ (m. nigrilenta), Karaman-2, 12.07.2009, E. Ilyina;

Distribution. Ancient-Mediterranean species, known from the Pyrenees to Altai, which spread in the investigated region within sandy landscapes of Caspian Sea shore and Volga valley. Typical unstriped morph prevails everywhere (Figure 43).

Noteworthy that in environs of Dosang (Charabaly fence) hitherto (2006) black-striped morph nigrilenta occurs besides typical morph as well uncommon, that qualifies the condition of the population of Low Volga as a high level of heterozygosity. For that population could be declare a state of donor for adjacent territories, where striped morph become extinct. At present, in Low Volga A. occitanica is included in Red book of Saratov Region (2006) and in the Black Sea shore in Red books of Krasnodar Region (2007) and Crimea (2015). A. occitanica-is a spectacular large species (Figure 44, 45), good ecological indicator for subtropical resorts.

Acanthaclisis occitanica is a good flying antlion. One of the last findings was made at high altitude in the mountains. The female was caught by Elena Ilyina in 6 July2018 at the upper boundary of the beech forest at an altitude of 1400 dpl. in Gimry ridge of the Caucasus in Buinaksk district of Dagestan, at the campus Terminlik.The Turano-Gobian A. pallida McL. from the same genus was included in matrix, as living in the eastern part of Northern Caspian shore abroad of Russia.

\section{Derivation of fauna}

Hereby evidence that North Caspian Coast of Russia is a heterogeneous zoogeographical area, covered with Caspian subprovince of Northern Turan and Kuro-Araxian provinces of Sethian Region, but all study territory situated undergo direct effect from three different faunistic centers of Myrmeleontidae, calculated for Palearctic fauna.



Figure 44. Acanthaclisis occitanica. Female of morpha typica from Middle Volga

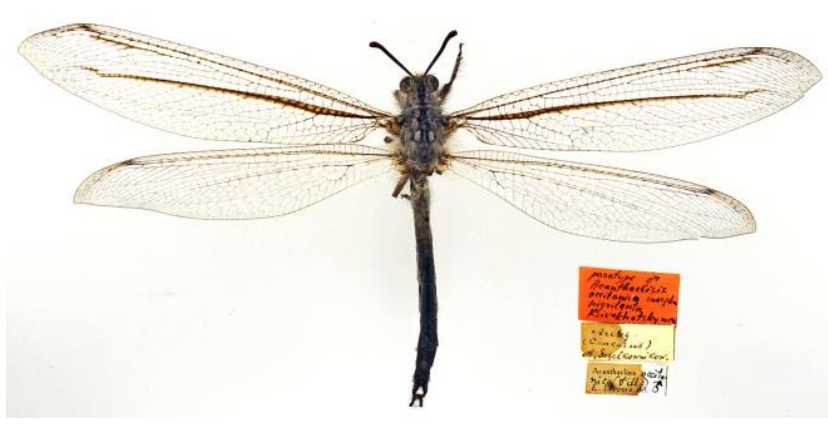

Figure 45. Acanthaclisis occitanica. Paratype, male of morpha nigrilenta from Azerbaijan 


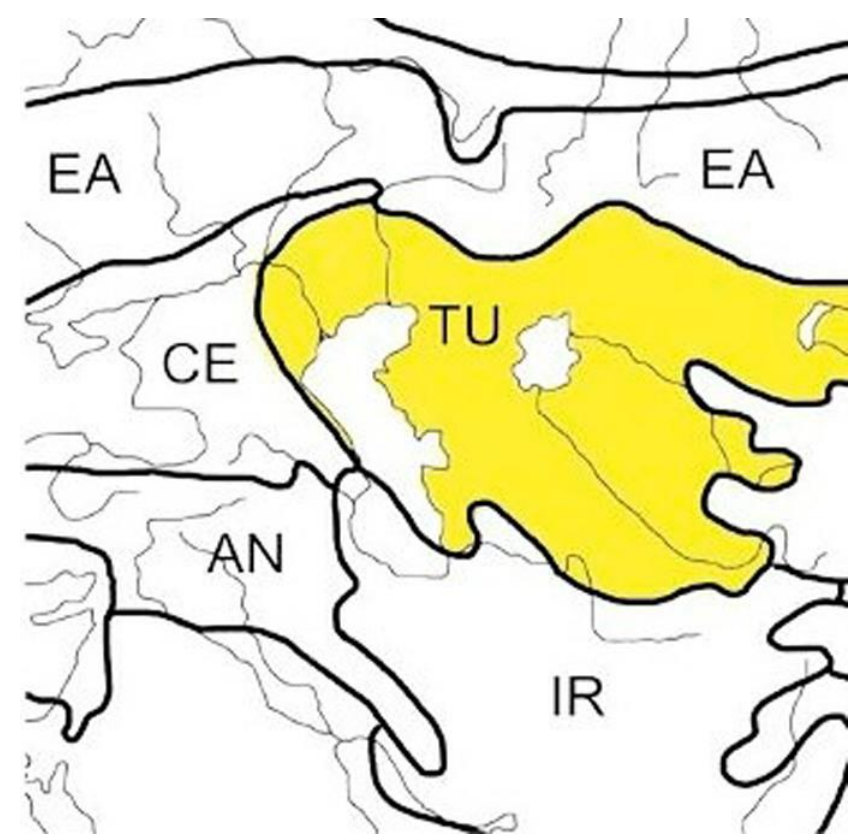

Figure 46. Influence of faunistic centers of Myrmeleontidae (after Krivokhatsky, Emeljanov, 2000; fragment). Elementary antlion faunas: AN-Anatolian; CE-Central European; EA-EuropeanAltai; IR-Iranian; TU-Turanian (yellow)

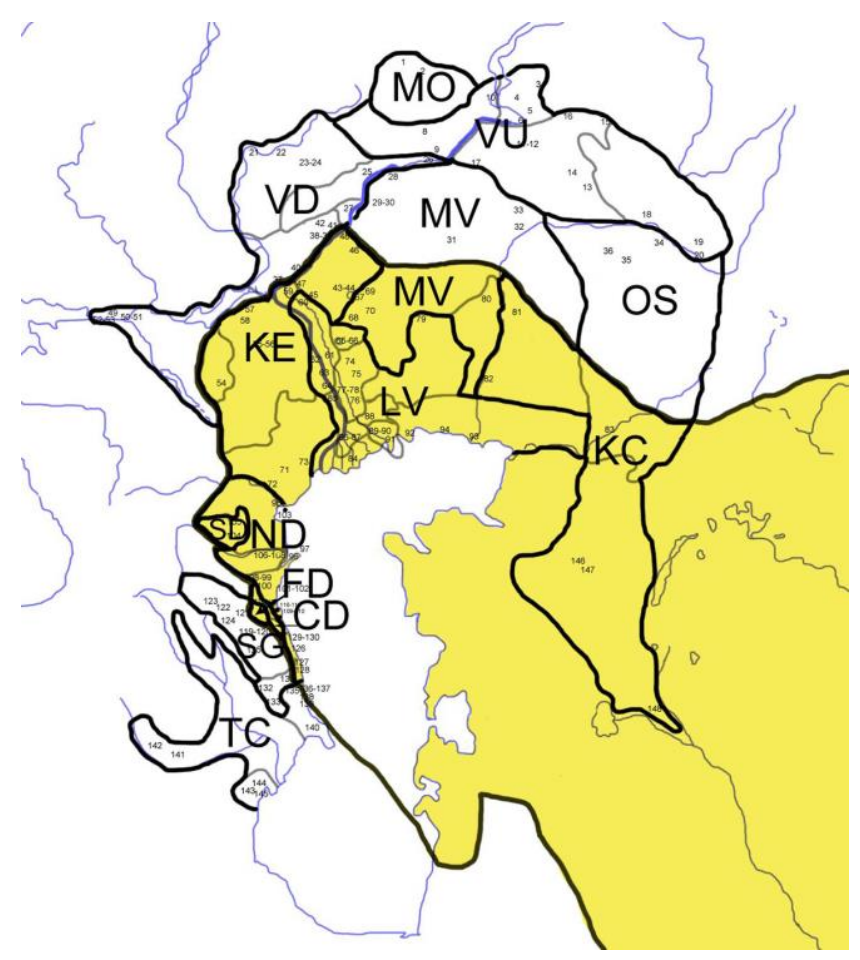

Figure 48. The distribution map of faunas in the Caspian region and the Volga-Ural interfluve corresponding to the Dendrogram with yellow zone under influence of the Turanian faunistic center. Designations as in Figure 5.
The considerable part of concrete fauna of the studied territories adjoining the coast of the Caspian Sea enters a zone of dwelling of the Turanian elementary fauna. A number of the created clusters (Figure 46) just situated in the territory of zoogeographical Northern Turan while the specific fauna of Middle Volga (MV) is the subject to the Turanian influence only in its southern half while its northern Volga-Ural primary fence is under the influence of the Central European and European-Altai faunae. In the Ordin cluster (OR), the Kalmyk-Elton fauna (KE) lives in the Turan zone, occupying vast valleys of the primary fences on both sides of the Volga (Figure 47). In the territory of Dagestan, similarly, the Turanian cluster SD united the non-connecting faunas of large valleys around the Terek.

It is noteworthy that none of the large blocks on the resulting dendrogram corresponds to a fauna that fully fits in the Turanian zone (Figure 48). The mixed composition of the fauna is largely associated with the natural interzonal passage of floodplain forests into the desert floodplains of large rivers and artificial gardening.

The leading role of Turan in the formation of the fauna of the antlions of the Caspian Sea and the Volga-Ural interfluve is determined.

\section{Improvements and continuation}

Shortage of primary regionalization, especially in Volga-Don and Volga-Ural interfluves can be revised with next special faunistic researches on other insects, or with geobotanical works.

In conclusion, zone of Turanian influence preferably includes primary fences characteristic for relative type of landscape-river brinks and sea shore. Common fauna adhered all over due to insistent means of spreading, named feng-shui spreading of antlions (Krivokhatsky, Kaverzina, 2012). Specimens from that group can be floated within cocoons and spread by water in long distance (shui type). Adult antlions fly themselves or under the impact of winds (feng type). Feng-shui spreading ensured survivance large species populations along sea shores and river beds, exposures tsunami and other disasters. Landscapes, integrated in other clusters, occupied antlions, which usually spread in adult stage only. Their populations inhabit zone of low risk for survival. The greatest biodiversity and, at the same time, high density of populations of Myrmeleontidae is observed in the primary areas of desert and steppe zones and in the corresponding ecotones. Thus, the family should be recognized evolutionary plastic mainly in periods of paleoclimatic katostrofy. 


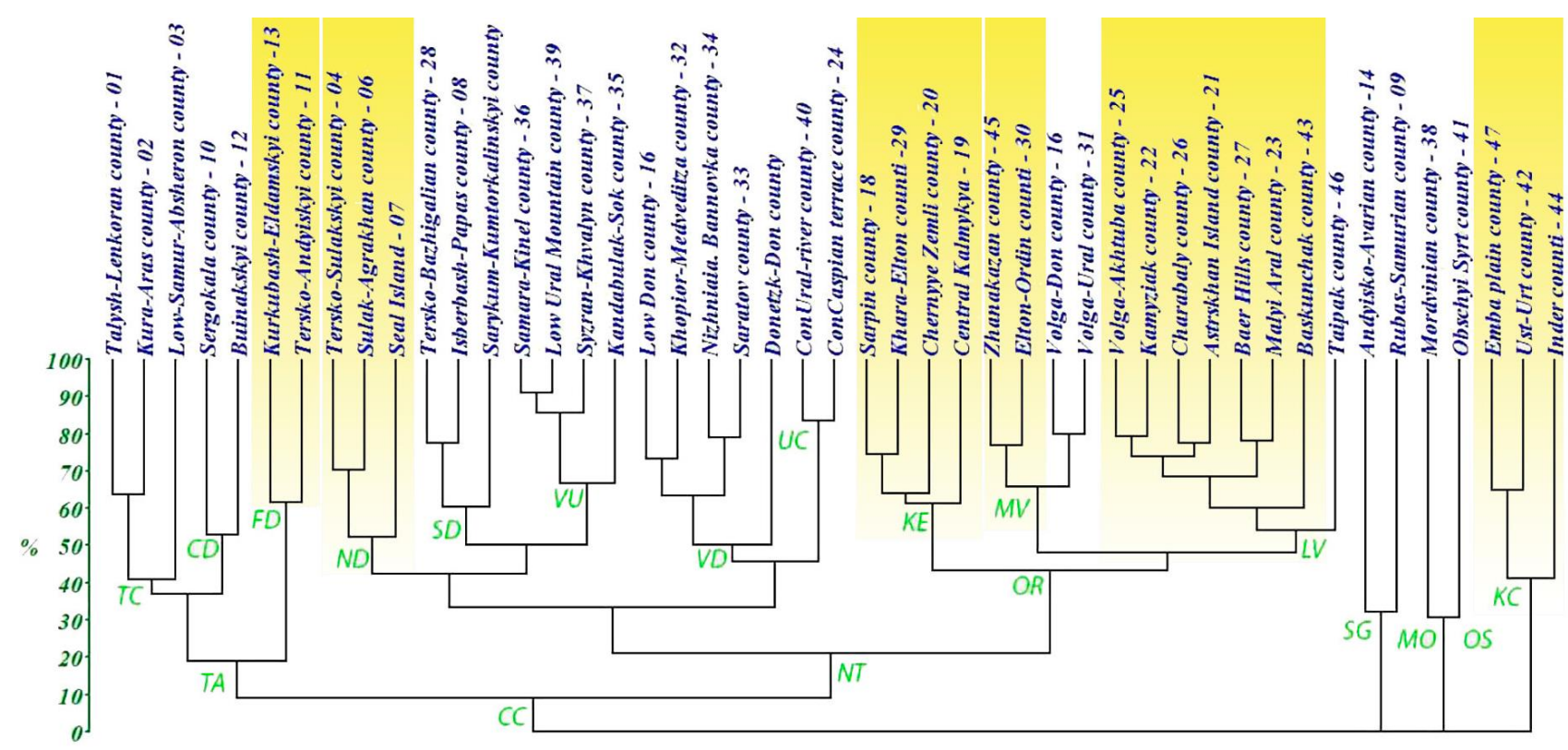

Figure 47. The Dendrogram, generated in programme CLA, with ehe relationship of concrete antlion faunas in connection with the position of the Northern Turan (yellow). Note: Concrete faunas: CC: ConCaspian, CD: Central Dagestan; FD: Foothill Dagestan; KE: Kalmyk-Elton; KC: Kaszakh-Caspian; ND: North Dagestanian; NT: NorthTuranian; LV: Lower-Volga; MO: Mordvinian county; MV: Middle-Volga; OR: Ordyn; OS: Obschyi Syrt county; SD: Sandy Dagestan; SG: Samur-Gunib concrete fauna; TA: Turano-Anatolian; TC: TransCaucasian; UC: Uralo-Caspian; VD: Volga-Don; VU: Volga-Ural.

\section{ACKNOWLEDGEMENTS}

We are grateful to G.N. Khabiev and A.S. Kurochkin our partners in Russian preliminary publication (Krivokhatsky et al. 2016). Also assistant of Neuroptera department Julia Samartseva advised us with looking around literature and relative collections. Photographs of antlions in nature were made by D. Astakhov (D.A.), A. Kurochkin (A.K.) E. Ilyina (E.I.) kindly provided us by colleagues P. Gorbunov (P.G.), and the late D. Piryulin (D.P.). Most materials, including comparative specimens are kept in Zoological Institute in St. Petersburg. The study performed in the frames of the state research project AAAA-A19-119020690082-8.

\section{REFERENCES}

Aspöck H, Aspöck U, Hölzel H. 1980. Die Neuropteren Europas. Joecke et Evers, Krefeld, B.1: 1-495, B.2, 1-355. [Russian]

Dobosz R. 1989. Siatkoskrzydte (Neuropteroidea) w Zbiorach Muzeum Jornoslaskiego w Bytomiu. Ann Upp Silesian Mus Bytom Nat Hist 12: 75-89. [Russian]

Dobosz R, Krivokhatsky V, Wąsala R, Plewa R, Aladshvili N. 2017. New data on the occurrence of lacewings (Neuroptera) in Georgia. Acta Entomola Silesiana. Bytom, February 10, 25 (online 002): 1-10.

Emeljanov AF. 1974. Proposals on the Classification and Nomenclature of Ranges. Entom Obozr 53 (3): 497-522.

Eversmann E. 1841. Quaedam insectorum species novae, in Rossia orientali observatae, nunc descriptae et depictae. Bulletin de la Société (Impériale) des Naturalistes de Moscou 14: 351-360.

Fedina AE. 1973. Physico-geographical zoning. Moscow University, Moscow.
Gvozdetsky NA. 1968. Physical-geographical zoning of the USSR. Moscow University, Moscow.

Hagen H. 1858. Russland Neuropteren. Stett Ent Zeitschr 19: 110-134.

Ilyina EV, Krivokhatsky VA. 2012. To the fauna of antlions (Neuroptera: Myrmeleontidae) of Daghestan. Caucasian Entomol Bull 8 (1): 159160.

Ilyina EV, Khabiev GN, Krivokhatsky VA. 2014. Myrmeleontoid lacewings (Neuroptera: Myrmeleontidae, Ascalaphidae) of Sarykum and environs. Proceedings of State Natural Reserve "Daghestanskyi" 5: 32-36.

Isachenko AG. 1985. Landscapes of the USSR. Leningrad.

Kerimova IG, Krivokhatsky VA. 2018. Current composition of the fauna of antlions (Neuroptera: Myrmeleontidae) of Azerbaijan. Caucasian Entomol Bull 14 (1): 55-66.

Khabiev GN, Krivokhatsky VA. 2014. Rare species of antlions (Neuroptera: Myrmeleontidae) new for the fauna of Caucasian and Middle Asian countries. Zoosystematica Rossica 23 (1): 122-126.

Krivokhatsky VA. Ovtshinnikova OG. 2011. Provinciality as the main principle in biogeographic regionalization. Entomol Oboz 90 (4): 861-866.

Krivokhatsky, V.A. 1993. On the development of the palaearctic ant-lions (Neuroptera, Myrmeleontidae) under the laboratory conditions. Izvestyia of the Kharkov Entomological Society 1 (2): 84-91. [Russian]

Krivokhatsky VA. 1998. Zoogeography of antlions of Palaearctic (Neuroptera, Myrmeleontidae). Meetings in memory of N.A. Cholodkovsky. St-Petersburg.

Krivokhatsky VA. 2000. Antlions (Neuroptera: Myrmeleontidae) of Ulianovsk Region. Insects and arachnids of Ulianovsk Region. Series "Nature of Ulianovsk Region". Iss. 9. Ulianovsk, 82-83.

Krivokhatsky VA. 2009. Discontinuity and sporadicity as species features. Species and speciation. Analysis of new views and trends. Proceedings of the Zoological Institute (Suppliment No. 1): 109-116.

Krivokhatsky VA. 2011. Antlions (Neuroptera: Myrmeleontidae) of Russia. Keys to the fauna of Russia published by the Zoological Institute of the Russian Academy of Sciences. Issue 174. KMK Scientific Press Ltd, St. Petersburg.

Krivokhatsky VA. 2012. New and interesting collecting of antlions (Neuroptera: Myrmeleontidae). Eversmannia 29-30: 40-41. 
Krivokhatsky VA., Anikin VV. 1996. Antlions (Neuroptera, Myrmeleontidae) of the Lower Volga Region. Izvestyia of the Kharkov Entomological Society 3 (1-2): 52-61.

Krivokhatsky VA, Anikin VV, Ovtshinnikova OG. 2003. To the question on the rarity of antlion Distoleon tetragrammicus (F.) (Neuroptera, Myrmeleontidae). Entomological and Parasitological Investigations in Povolzh'e Region, Saratov University Press 2: 123-124.

Krivokhatsky VA, Anikin VV, Astakhov DM, Astakhova AS, Khabiev GN, Kurochkin AS, Plotnikov IS. 2016. New records of the Low and Middle Volga antlions (Neuroptera, Myrmeleontidae) and analysis of particular fauna's distribution. Entomological and Parasitological Investigations in Povolzh'e Region, Saratov University Press 13: 7 31 .

Krivokhatsky VA, Dobosz R. Khabiev GN. 2015. Antlions and owlflies (Neuroptera: Myrmeleontidae, Ascalaphidae) of Kyrgyzstan // Entomologicheskoe Obozrenie 94 (3-4): 803-818.

Krivokhatsky VA, Emeljanov AF. 2000. Use of general zoogeographical subdivisions in particular zoogeographical researches for the example of the Palaearctic antlions fauna (Neuroptera, Myrmeleontidae). Entomol Oboz 79 (3): 557-578.

Krivokhatsky VA, Emeljanov AF, Lobanov AL. 1996. The distribution of antlions in Mongolia (Insecta: Neuroptera: Myrmeleontidae). In Canard M, Aspock H, Mansell MW (eds.). Pure and Applied Research in Neuropterology. Proceedings of the Fifth International Symposium on Neuropterology. Cairo, Egypt, 1994. Toulouse, France.

Krivokhatsky VA, Hajiesmailian A, Mirmoayedi A, Khabiev G, Dobosz R, Ostroverkhova M. 2017. Palpares turcicus Koçak, 1976-new name for Iranian fauna and its place in the P. libelluloides species group (Neuroptera: Myrmeleontidae). Proceedings of the Zoological Institute 321 (4): 377-402.

Krivokhatsky VA, Kaverzina AS. 2012. About insistent means of spreading on antlions (Neuroptera: Myrmeleontidae). Caucasian Entomol Bull 8 (4): 254-256

Krivokhatsky VA, Piryulin DD. 1997. Composition, origin, and current changes of Myrmeleontidae (Neuroptera) fauna in the Aral. Sea Region. Zoologicheskyi Zhurnal 76 (10): 1150-1159.

Krivokhatsky VA, Rokhletzova AV. 2004. New data on Neuropteroidea (Neuroptera, Raphidioptera) of Low Volga Region. Entomological and Parasitological Investigations in Povolzh'e Region, Saratov University Press 3: 36-39.

Krivokhatsky VA, Zhiliang W, Xinli W. 2012. New records and new synonyms of antlions (Neuroptera, Myrmeleontidae). Entomol Rev 93 (5): 572-583

Krivokhatsky VA., Zakharenko AV. 1996. Notes on the antlions (Neuroptera, Myrmeleontidae) of the Ryn-Desert, Western
Kazakhstan. Izvestyia of the Kharkov Entomological Society 3 (1-2): 62.

Makarkin VN, Ruchin AB. 2014. A contribution to the knowledge of Neuroptera and Raphidioptera of Mordovia (Russia). Caucasian Entomol Bull 10 (1): 111-117.

McLachlan R. 1867. New Genera and Species Neuropterous Insects; and a revision of Mr. F. Walker's British Museum Catalogue of Neuroptera, Part II (1853), as far as the end of the genus Myrmeleon. J Linnean Soc London Zool 9: 230-281.

McLachlan R. 1878. Neuroptera. In: Scientific results of the second Jarkand Mission Calcutta 13: 1-6.

Mirmoayedi A. 2006. New research of some of Iranian antlions (Insecta, Neuropterida, Neuroptera, Myrmeleontidae). Iranian J Anim Biosyst 2 (1): 47-55.

Mirmoayedi A, Zakharenko AV, Krivokhatsky VA, Yassayie A. 1998. To the fauna of lacewings (Insecta: Neuroptera) of the National Park and the Kermanshah Province (Iran). Isvestia of the Kharkov Entomological Society 6 (2): 53-56.

Pallas PS. 1771. Myrmeleo trigrammus. In Reise durch verschiendene Provinzen des Russischen Reiches in den Jahren, 1768-1769. Akad Buch St. Petersburg Bd 1: 469.

Plotnikov IS, Sidorenko VC, Krivokhatsky VA. 2013. Zoogeographic analysis of the Palaearctic fauna of fruit flies (Diptera, Drosophilidae) with description of clusterization software for provincial faunas. Entomol Oboz 92 (1): 102-119.

Rokhletzova AV. 2000. Materials to the fauna of lacewings (Neuroptera) of Ulianovsk Region. Natura of Simbyrsk Povolzh'e. Ulijanovskiy State Technical University press, Ulijanovsk.

Rokhletzova AV, Krivokhatsky VA. 2006. To the knowledge of the Volga-Uralensis lacewings (Neuroptera). Entomological and parasitological investigations in Povolzh'e Region, Saratov University Press 5: 23-30.

Sharonova IV, Kuruchkin AS. 2015. Botanical and Zoological research in the Samara region, including materials on the distribution of plant and animal species included in the regional Red book. Communication 1. Samarskaya Luka 24 (1): 38-97.

Ulianin V. 1869. List of the Neuropteroid and Orthopteroid Insects from the provinces of Moscow school district. News of the Society of Lovers of Natural Science and Ethnography SPb 6 (2): 1-220.

Yakowleff W. 1869. Materialien zur Entomologischen Fauna der WolgaGegend. Horae Soc Ent Ross 6 (3): 109-126.

Zakharenko AV. 1983 Antlions of the genus Aspoeckiana Hölzel (Neuroptera, Myrmeleonidae) of the fauna of the USSR. Entomol Oboz 62 (3): 586-589.

Zakharenko AV, Krivokhatsky VA. 1993. Neuroptera from the European part of the former USSR. Izvestyia of the Kharkov Entomological Society 1 (2): 34-83. 